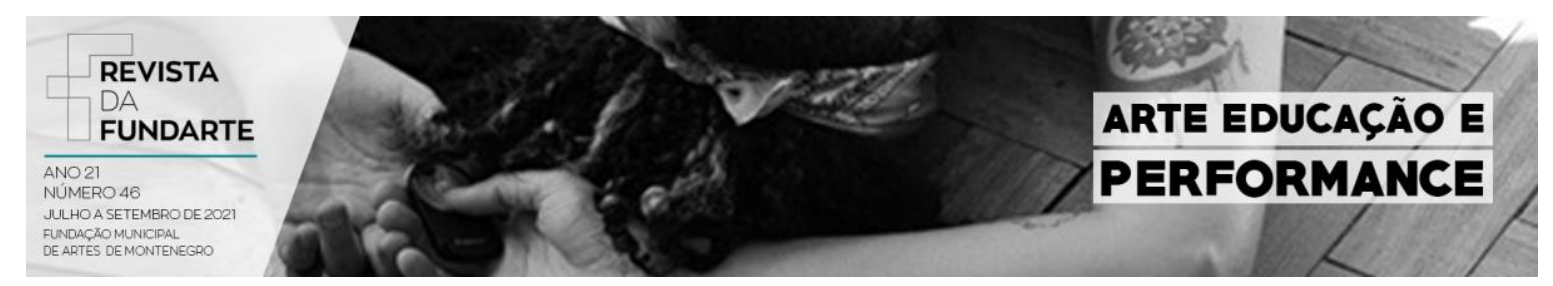

ENTRE A RUÍNA E O ATELIÊ: UMA IMERSÃO POÉTICA

\author{
Susana Tebaldi Toledo \\ Mariana Silva da Silva
}

DOI: http://dx.doi.org/10.19179\%2F2319-0868.886

TOLEDO, Susana Tebaldi; SILVA, Mariana Silva da. Entre a ruína e o ateliê: uma imersão poética. Revista da FUNDARTE. Montenegro, p.01-25, ano 21, no 46, setembro de 2021.

Disponível em: http://seer.fundarte.rs.gov.br/index.php/RevistadaFundarte/issue/archive $>30$ de setembro de 2021. 


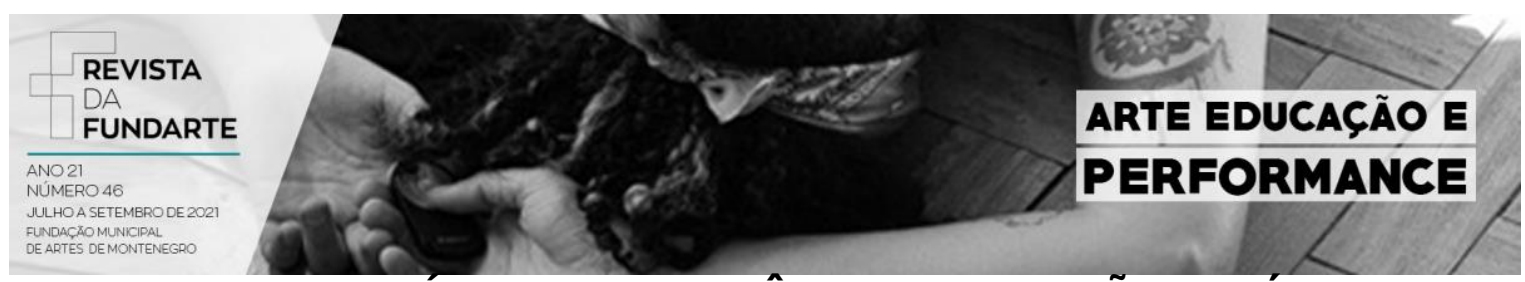

\title{
ENTRE A RUÍNA E O ATELIÊ: UMA IMERSÃO POÉTICA
}

Susana Tebaldi Toledo'

Mariana Silva da Silva²

\begin{abstract}
Resumo: $O$ presente artigo apresenta um recorte da investigação realizada em uma casa em ruínas, no centro da cidade de Montenegro/RS, como uma imersão poética, que deseja dar a ver as camadas de tempo e espaço que se sobrepõem em um processo artístico cotidiano. Analisando as possibilidades para a criação em arte nesse espaço em transformação, muitas vezes considerado inútil, incômodo e que atrapalha o desenvolvimento do espaço urbano. Ao habitar a casa como um ateliê, propomos alterações e diferentes vivências neste espaço. Considerando, ainda, a forma que as plantas e demais seres dialogam com a casa em ruínas, visualiza-se fissuras nos modos que a arte pode se relacionar com a vida e o cotidiano.
\end{abstract}

Palavras-chave: Imersão poética; Ateliê; Habitar.

\section{IN THE MIDDLE OF THE RUIN AND THE ATELIER: A POETIC IMMERSION}

\begin{abstract}
The following article presents a fraction of the investigation in a ruined house in Montenegro/RS as a poetic immersion who wants to show how layers of time and space overlap on the daily artistic process. Looking for the possibilities to create art in this changing space often considered useless, uncomfortable and that hindered the development of urban space. When inhabiting the house as an atelier. When inhabiting the house as an atelier we propose changes and different experiences in this space. Also considering the way that plants and other beings dialogue with the house in ruins, we can attempt to promote clefts in the ways that art can relate to life and quotidian.
\end{abstract}

Keywords: Poetic Immersion; Atelier; Inhabit.

\footnotetext{
${ }^{1}$ Bacharela em Relações Públicas pela Universidade Federal de Santa Maria, licenciada em Artes Visuais pela Universidade Estadual do Rio Grande do Sul - UERGS. Foi bolsista do Programa Institucional de Bolsa de Iniciação à Docência - PIBID/CAPES/UERGS - Subprojeto de Artes Visuais durante os anos de 2016 e 2017. Participou da pesquisa do projeto de doutorado em ARTES VISUAIS - História, Teoria e Crítica pelo PPGAV/UFRGS, do professor e doutorando Igor Moraes Simões, intitulada "História da Arte e montagem: a exposição como dispositivo". Foi editora de vídeos na TV Cultura do Vale entre 2017 e 2018. Atuou como Mediadora da 11 ${ }^{\text {a }}$ Bienal do Mercosul no ano de 2018. Atualmente, atua como Mediadora Estagiária no Museu de Arte de Montenegro (MAM), participa do Projeto de Pesquisa "O infraordinário como método investigativo em Arte \& Educação" coordenado pela Professora Dra. Mariana Silva da Silva e é integrante da Rede de Mediadores da Galeria de Arte Loide Schwambach, da Fundação Municipal de Artes de Montenegro - FUNDARTE atuando na Exposição Salão 10x10 - 7ª edição.

2 Professora Adjunta da Universidade Estadual do Rio Grande do Sul (UERGS). Doutora em Artes Visuais, Ênfase Poéticas Visuais no Instituto de Artes da Universidade Federal do Rio Grande do Sul (UFRGS), com estágio junto à Faculté des Arts da Université de Picardie Jules Verne (Amiens, França). Mestre em Artes Visuais e Bacharel em Artes Plásticas pela Universidade Federal do Rio Grande do Sul (UFRGS). Recebeu Bolsa CAPES Mestrado (2002-2004), Bolsa Unesco Aschberg e Irish Museum of Modern Art para projeto Residência de artista (2008) e Bolsa CAPES PDSE Doutorado Sanduíche (2017). Participa de exposições de artes visuais no Brasil e no exterior desde 2001, é professora universitária desde 2005. Investiga as conexões entre arte, cotidiano e natureza.
}

TOLEDO, Susana Tebaldi; SILVA, Mariana Silva da. Entre a ruína e o ateliê: uma imersão poética. Revista da FUNDARTE. Montenegro, p.01-25, ano 21, no 46, setembro de 2021.

Disponível em: http://seer.fundarte.rs.gov.br/index.php/RevistadaFundarte/issue/archive $>30$ de setembro de 2021. 


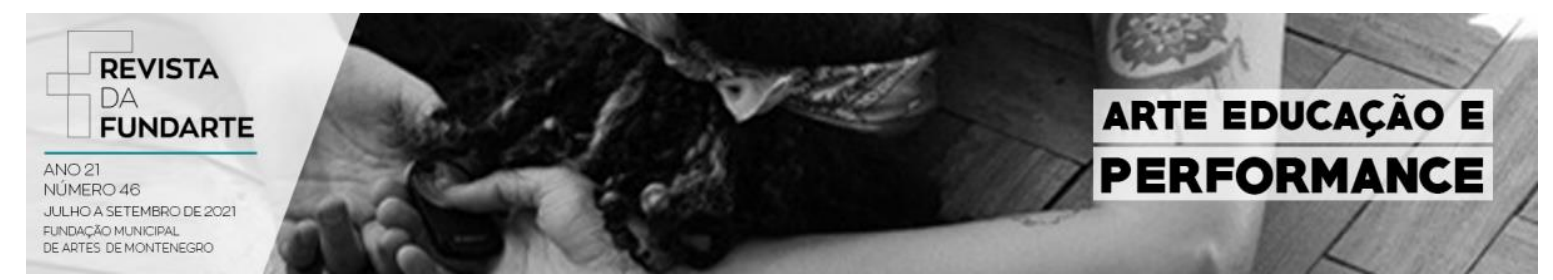

\section{INTRODUÇÃO}

No presente artigo, apresentamos um recorte de uma investigação que buscou tensionar o espaço público e privado através de uma experimentação em arte, partindo do conceito de imersão, que desencadeia uma experiência artística vinculada ao cotidiano, ruína e ateliê com o intuito de ocasionar fissuras semânticas nesses contextos.

A proposta artística consistiu em habitar uma casa (Figura 1), no centro da cidade de Montenegro/RS, que está em ruína, por meio de uma imersão poética que possibilitou experimentar diferentes proposições no espaço, com a ideia de um fazer constante e processual, transformando-o em um ateliê.

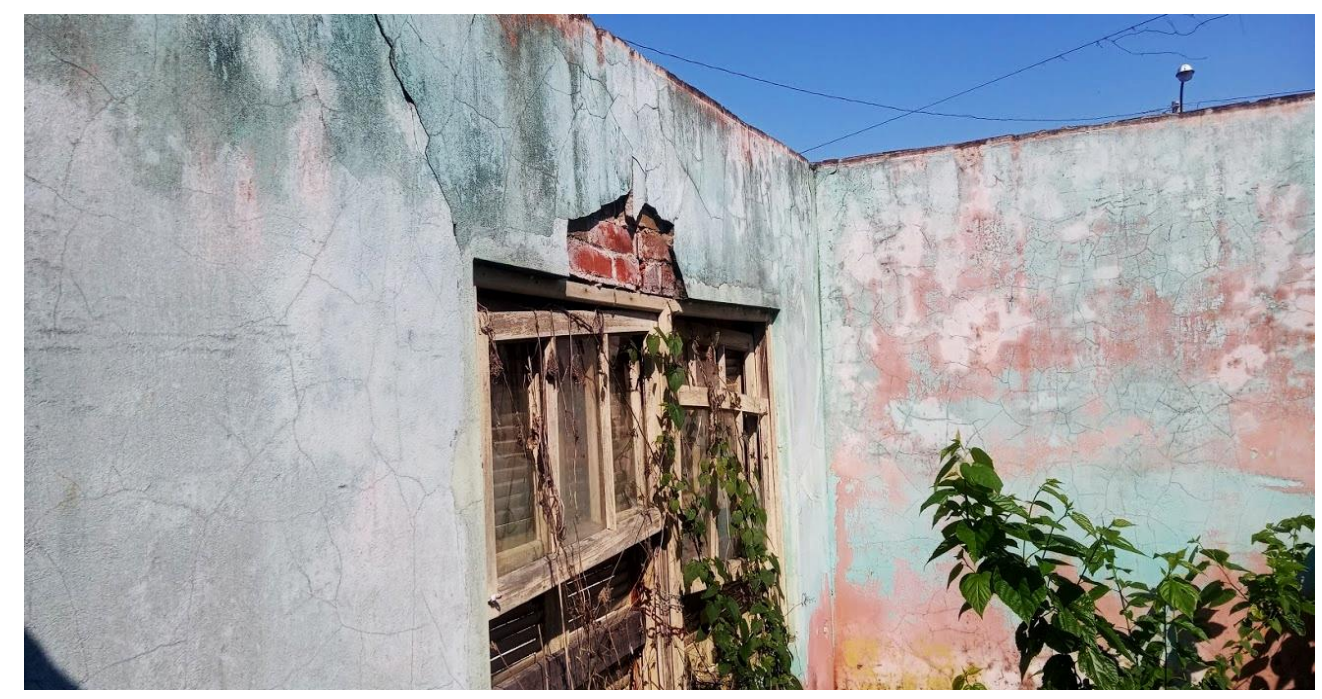

Figura 1 - Casa em ruínas. Acervo pessoal, 2020

A partir do espaço que foi escolhido para habitar, a casa em ruína, localizada no centro de Montenegro/RS, dialogamos com o conceito de ruína na arte a partir do livro El tiempo en ruinas (2003), do autor Marc Augé, e analisamos as possibilidades de um ateliê a partir de artistas como Fernanda da Silva, Paola Zordan e Marcelo Forte.

TOLEDO, Susana Tebaldi; SILVA, Mariana Silva da. Entre a ruína e o ateliê: uma imersão poética. Revista da FUNDARTE. Montenegro, p.01-25, ano 21, no 46, setembro de 2021.

Disponível em: http://seer.fundarte.rs.gov.br/index.php/RevistadaFundarte/issue/archive $>30$ de setembro de 2021. 


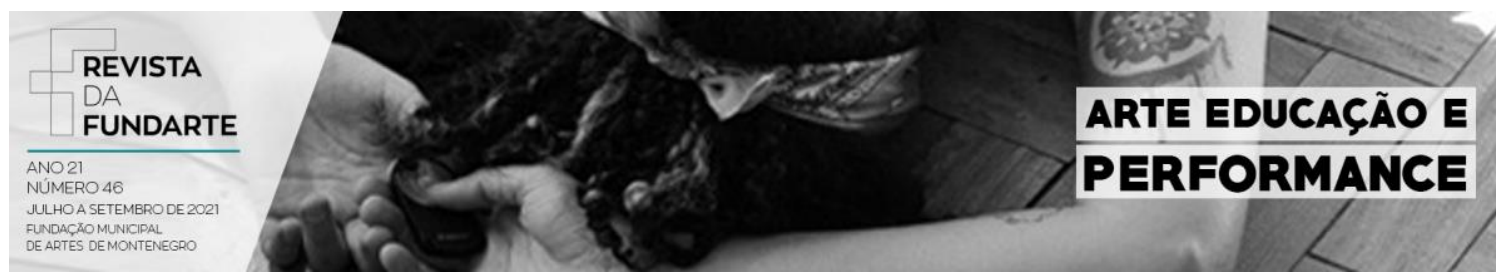

Ao longo do processo de imersão, nesse espaço habitado como um ateliê, foram realizadas algumas proposições artísticas. Os cômodos da casa abrigam diferentes experimentações, dialogando e questionando a ideia de ordem doméstica, conceito abordado pelo autor Emanuele Coccia, em seu texto "Revertendo o novo monasticismo global" (2020). Também é pensada a questão da imersão poética, a partir de Coccia, em seu livro "A Vida das Plantas: uma metafísica da mistura" (2018), sobre a ideia de imersão. É possível, ainda, fazer reflexões acerca da experiência de habitar essa casa/ateliê através do pensamento de Gaston Bachelard, em seu texto "A Poética do Espaço" (2003), em que diz: "[...] o espaço habitado transcende o espaço geométrico" (BACHELARD, 2003, p. 62), pensando nos possíveis sentidos que o espaço da casa entre ruína e ateliê pode inventar.

Assim, a pesquisa buscou compreender como as proposições artísticas acontecem nesta casa a partir das experimentações, imersão e habitação. Como se dá a criação de um ateliê artístico em um espaço em constante transformação, ora casa, ora ruína? Que operações artísticas poderiam habitar esse espaço? Que relações entre o cotidiano já estabelecido no espaço e as interferências vão acontecendo? Como a arte e a vida podem dialogar entre si na casa/ruína/ateliê? Tais questões permearam a investigação até este momento, entrelaçadas por outras inquietações que motivam a seguir a pesquisa.

\section{CASA, RUÍNA E ATELIÊ: Um espaço possível para a arte}

Apresentaremos o espaço escolhido para a investigação: a casa em ruínas (Figura 2); e a perspectiva de ateliê a partir de determinadas vivências cotidianas no local. A partir do autor Marc Augé, em seu livro "El tiempo en ruinas" (2003), pensamos nela e em seu tempo, na ideia de que

A contemplação das ruínas nos permite ver fugazmente a existência de um tempo que não é o tempo de que falam os manuais de história ou dos que procuram ressuscitar as restaurações. É um tempo puro, que não se pode datar, que não está presente em nosso mundo de imagens, simulacros e reconstituições, que não se localiza em nosso mundo violento, um mundo

TOLEDO, Susana Tebaldi; SILVA, Mariana Silva da. Entre a ruína e o ateliê: uma imersão poética. Revista da FUNDARTE. Montenegro, p.01-25, ano 21, no 46, setembro de 2021.

Disponível em: http://seer.fundarte.rs.gov.br/index.php/RevistadaFundarte/issue/archive $>30$ de setembro de 2021. 


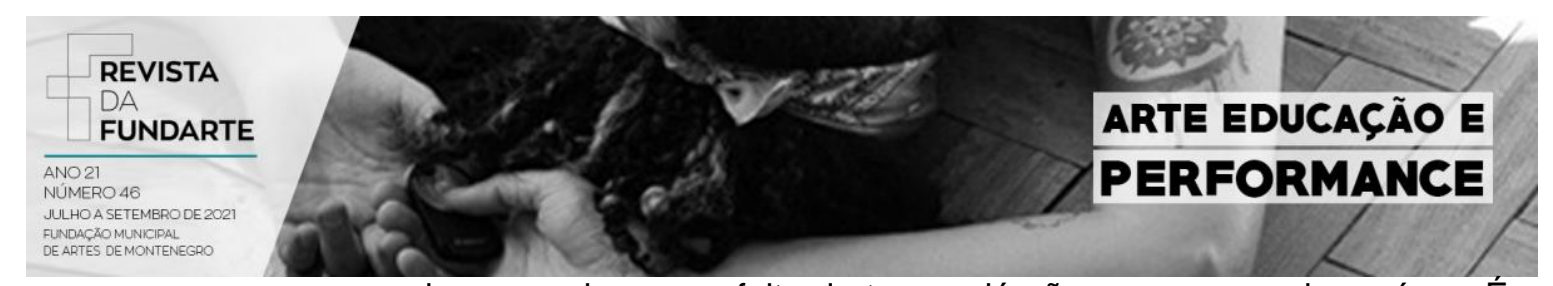

cujos escombros, por falta de tempo, já não conseguem virar ruínas. É um tempo perdido cuja recuperação compete à arte. ${ }^{3}$ (AUGÉ, 2003, s/p., tradução nossa).

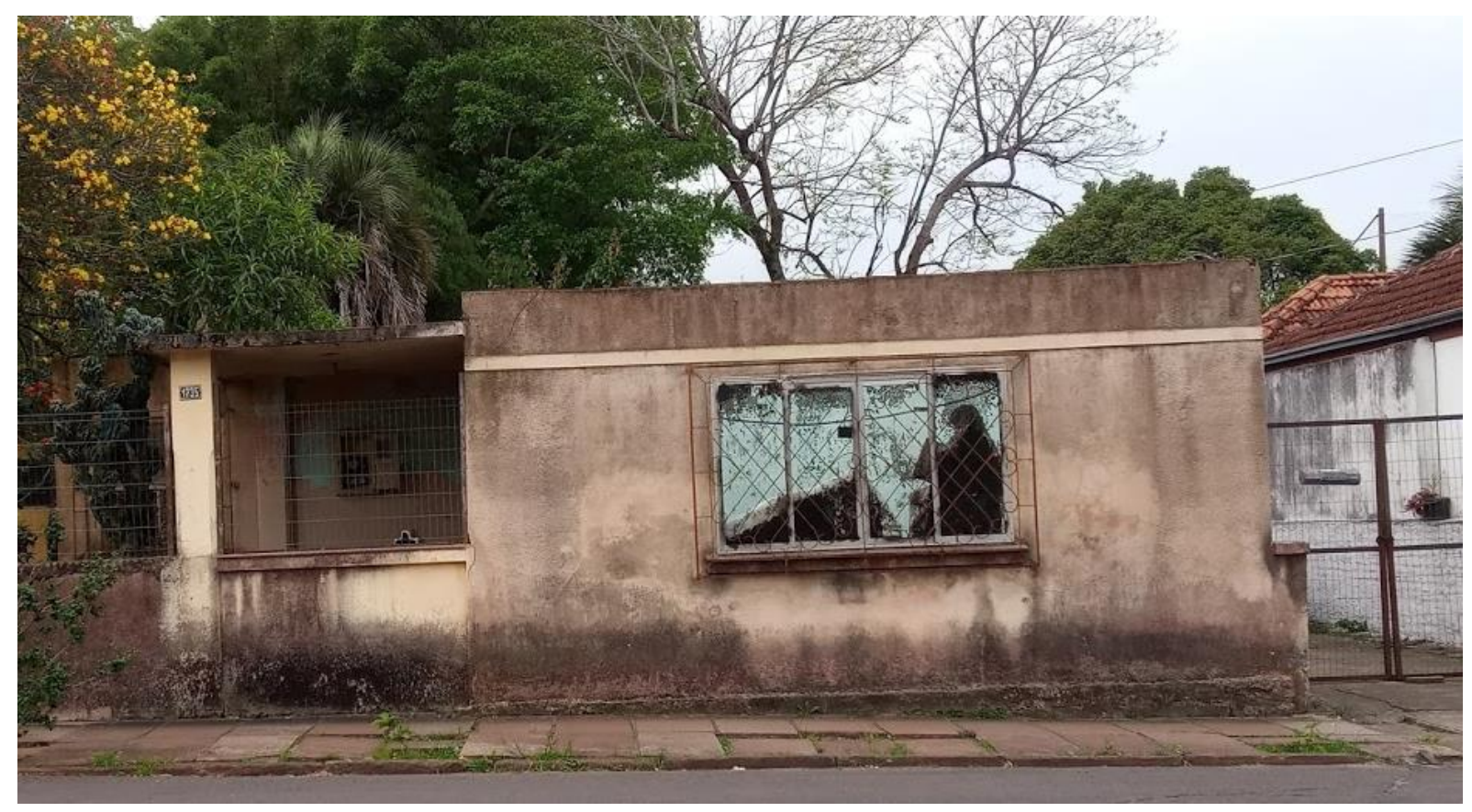

Figura 2 - Fachada da casa em ruína. Fonte: Acervo pessoal (2020).

A efemeridade das ruínas pode ser percebida através das constituições materiais que vão se modificando pela ação do próprio tempo, além da ação que é promovida pelo habitar de plantas, seres e pessoas. Entender as ruínas como espaços que transcendem a sua materialidade é possibilitar a construção de um lugar poético, conforme destaca Ferreira:

[...] de transcurso de lembranças, de memórias que são poetizadas e que estão materializadas em cada pequeno canto da casa, configurando-se, pois, de um espaço vivido. [...] temos lembranças dos lugares que habitamos e dos lugares que nos habitam. (FERREIRA, 2006, p. 2).

\footnotetext{
${ }^{3}$ No original: La contemplación de las ruinas nos permite entrever fugazmente la existencia de un tiempo que no es el tiempo del que hablan los manuales de historia o del que tratan de resucitar las restauraciones. Es un tiempo puro, al que no puede asignarse fecha, que no está presente en nuestro mundo de imágenes, simulacros y reconstituciones, que no se ubica en nuestro mundo violento, un mundo cuyos cascotes, faltos de tiempo, no logran ya convertirse en ruinas. Es un tiempo perdido cuya recuperación compete al arte.
}

TOLEDO, Susana Tebaldi; SILVA, Mariana Silva da. Entre a ruína e o ateliê: uma imersão poética. Revista da FUNDARTE. Montenegro, p.01-25, ano 21, no 46, setembro de 2021.

Disponível em: http://seer.fundarte.rs.gov.br/index.php/RevistadaFundarte/issue/archive $>30$ de setembro de 2021. 


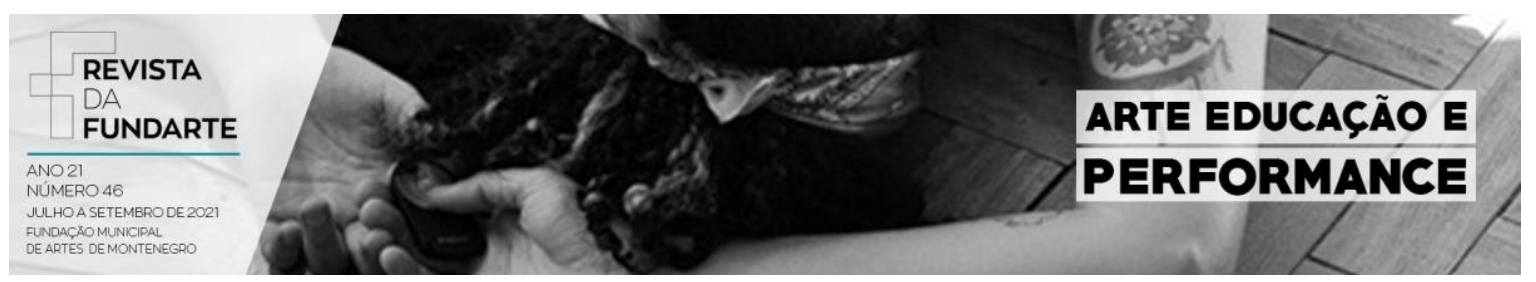

Em um movimento não-linear, habitar uma ruína, que um dia foi moradia de uma família, faz o pensamento viajar pelo passado, recordando os mais diversos lugares: casas, apartamentos, parques, estradas, praças. Cada espaço é um pequeno universo e, como afirma Bachelard, nessa troca dinâmica entre seres e lugares, "[...] estamos longe de qualquer referência às simples formas geométricas. A casa vivida não é uma caixa inerte. $O$ espaço habitado transcende o espaço geométrico" (BACHELARD, 2003, p. 62).

As casas em ruínas, muitas vezes, são silenciadas através da rapidez do olhar. Para Ferreira (2006), elas são emudecidas, pois o tecido urbano tornou-se local de passagem e, em meio à pressa, a expressão do detenimento do olhar foi diminuída (FERREIRA, 2006, pp.2-3).

Habitar a ruína e ocupá-la através da arte pode ressaltar os traços de uma memória-lugar que ficaram impregnados nas paredes. Não necessariamente memórias de quem já viveu naquele espaço, mas uma paisagem memorial construída a partir da vivência e imaginação de quem adentra a casa. Como afirma Bachelard (2003, p. 71):

Então, se mantivermos o sonho da memória, se ultrapassarmos a coleção das lembranças precisas, a casa perdida na noite dos tempos sai da sombra, parte por parte. Nada fazemos para reorganizá-la. Seu ser se reconstitui a partir de sua intimidade, na doçura e na imprecisão de sua vida interior.

Antes de iniciar as proposições artísticas no espaço, a imersão acontece através da fotografia, registrando detalhes e as minúcias da ruína. Uma árvore dentro de um cômodo e telhas pelo chão (Figura 3) é encontrada, azulejos e algo que lembra uma pia de cozinha (Figura 4); todos os cômodos sem teto, com apenas o céu figurando um possível telhado (Figura 5).

TOLEDO, Susana Tebaldi; SILVA, Mariana Silva da. Entre a ruína e o ateliê: uma imersão poética. Revista da FUNDARTE. Montenegro, p.01-25, ano 21, no 46, setembro de 2021.

Disponível em: http://seer.fundarte.rs.gov.br/index.php/RevistadaFundarte/issue/archive $>30$ de setembro de 2021. 

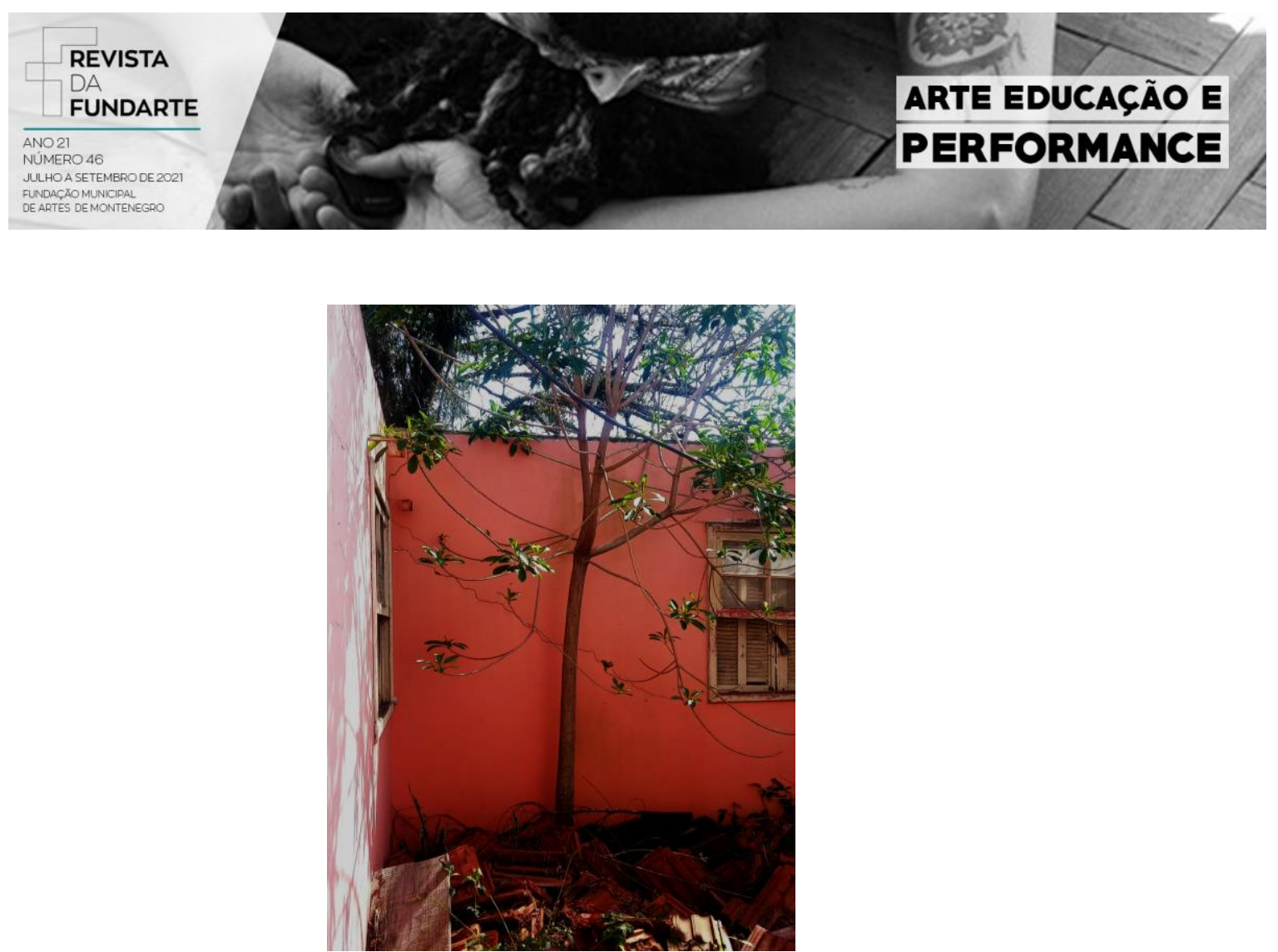

Figura 3 - Árvore habitando um cômodo. Fonte: Acervo pessoal (2020).

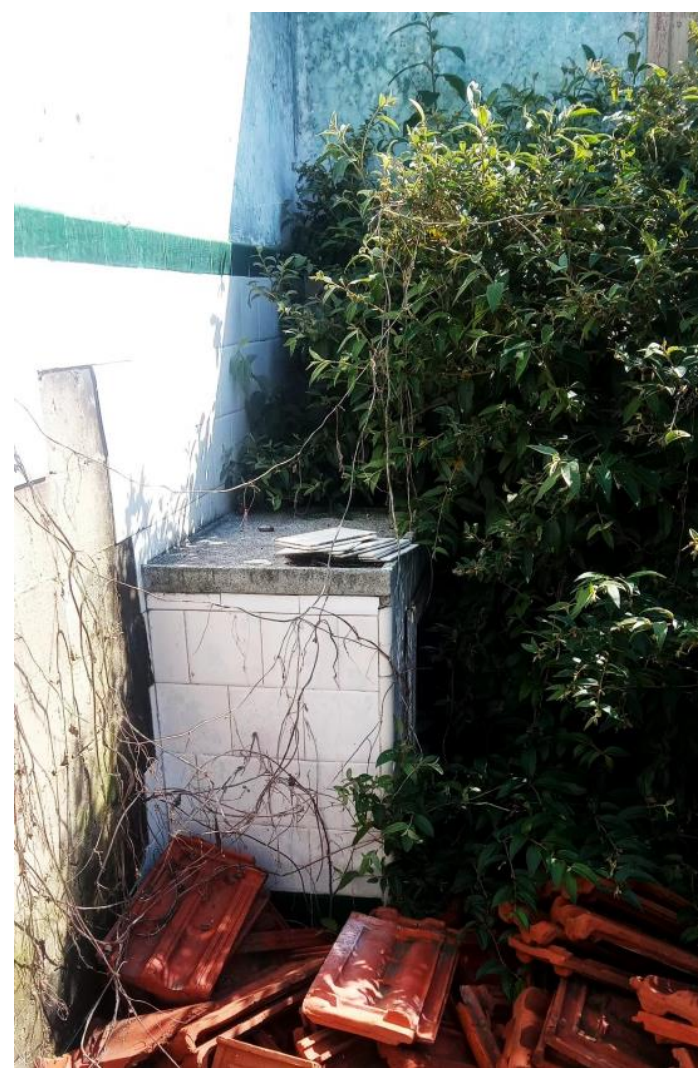

Figura 4 - Azulejos e pia. Fonte: Acervo pessoal (2020).

TOLEDO, Susana Tebaldi; SILVA, Mariana Silva da. Entre a ruína e o ateliê: uma imersão poética. Revista da FUNDARTE. Montenegro, p.01-25, ano 21, no 46, setembro de 2021.

Disponível em: http://seer.fundarte.rs.gov.br/index.php/RevistadaFundarte/issue/archive $>30$ de setembro de 2021. 

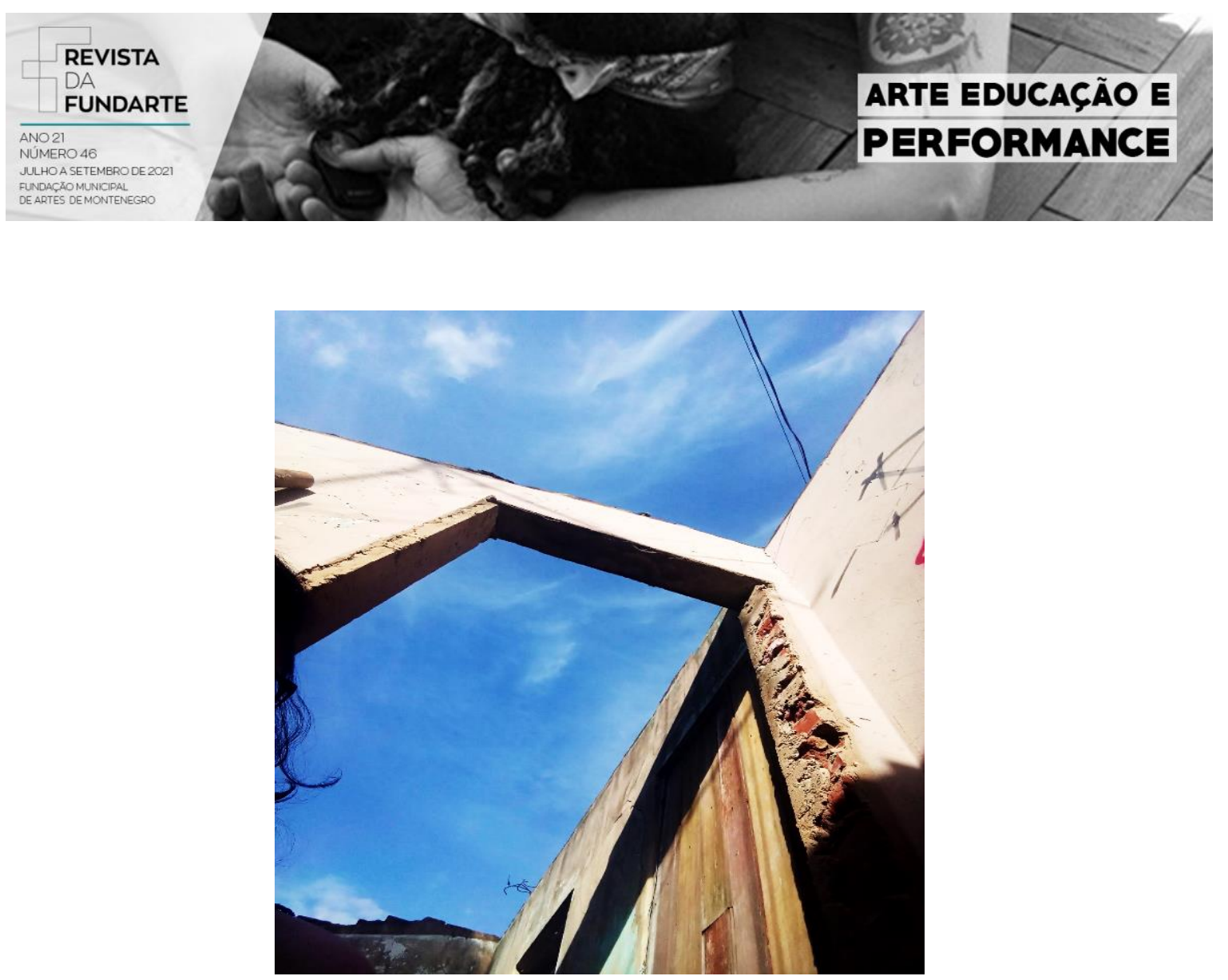

Figura 5 - Cômodos sem teto. Fonte: Acervo pessoal (2020).

Ao adentrar outro cômodo, uma caixa de descarga (Figura 6), um vaso, uma pia e uma banheira. Vários azulejos e um espaço onde possivelmente havia um chuveiro.

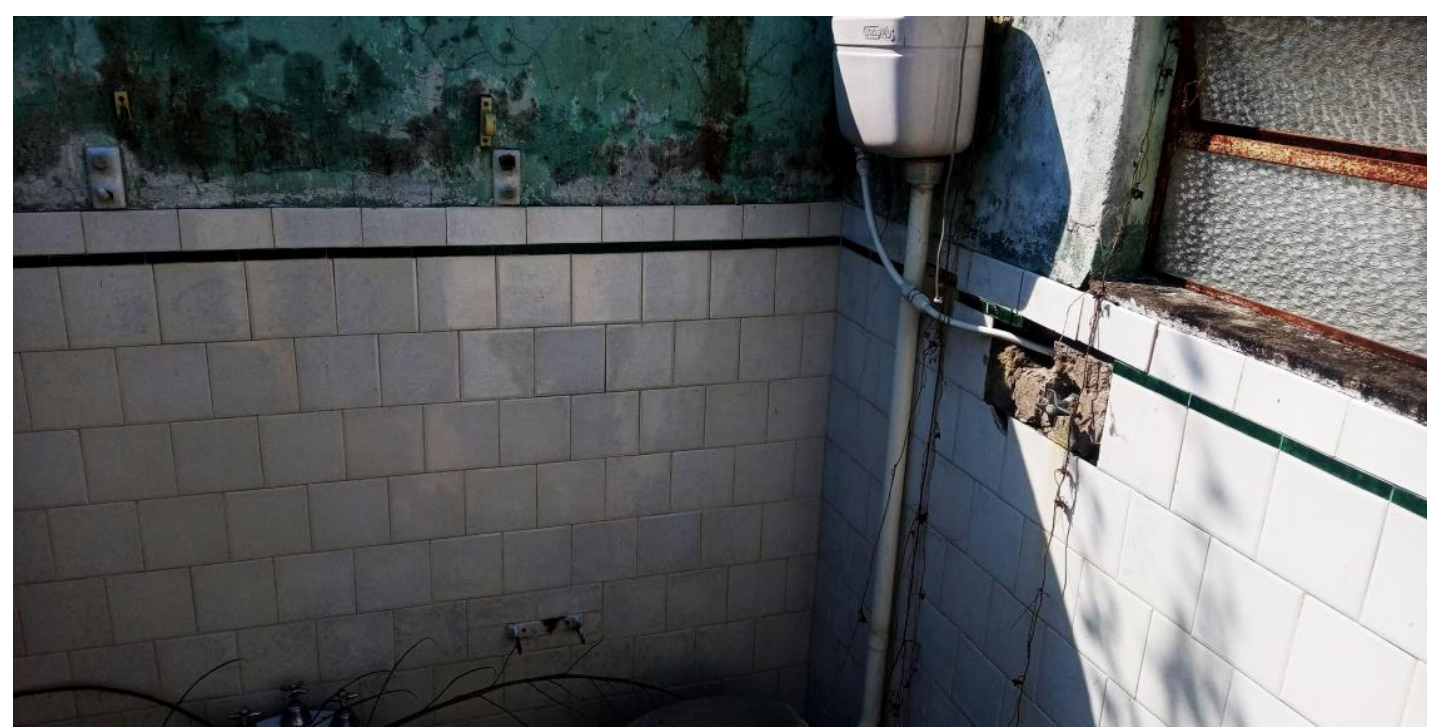

Figura 6 - Parte do cômodo que é identificado como banheiro. Fonte: Acervo pessoal (2020).

TOLEDO, Susana Tebaldi; SILVA, Mariana Silva da. Entre a ruína e o ateliê: uma imersão poética. Revista da FUNDARTE. Montenegro, p.01-25, ano 21, no 46, setembro de 2021.

Disponível em: http://seer.fundarte.rs.gov.br/index.php/RevistadaFundarte/issue/archive $>30$ de setembro de 2021. 

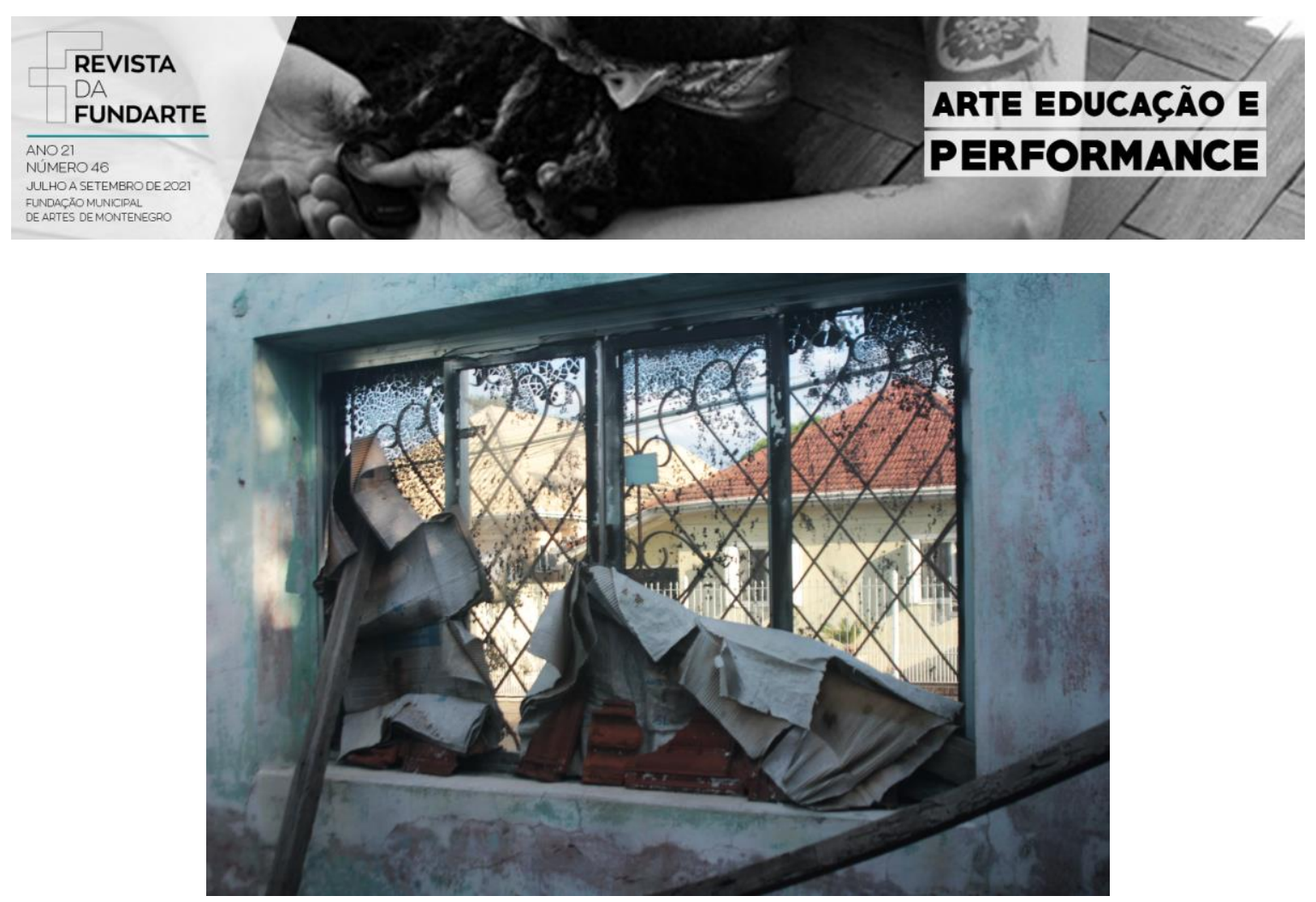

Figura 7 - Janela da fachada com papelões. Fonte: Acervo pessoal (2020).

Na janela da fachada da casa, que dá para a rua, alguns papelões (Figura 7) parecem ser uma tentativa de esconder algo, para cobrir a parte transparente dos vidros. Em uma das conversas com a proprietária da casa, ela relata se sentir bastante incomodada com a aparência das ruínas e com a não utilidade da casa. Gostaria de reformá-la, de poder voltar a morar nela, mas conflitos familiares a impedem. Além de objetos e seres inanimados, as plantas e como elas habitam a casa vão chamando a atenção (Figura 8).

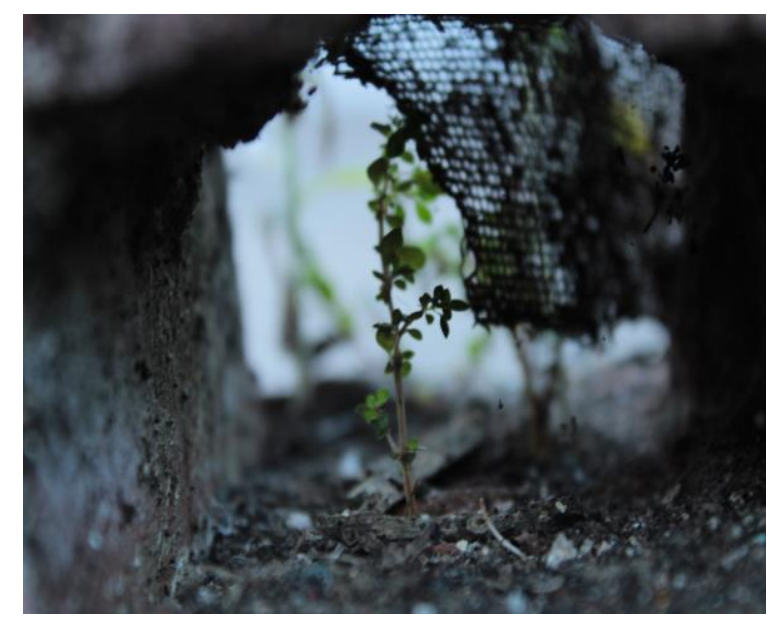

Figura 8 - Detalhe do rodapé da casa. Fonte: Acervo pessoal (2020).

TOLEDO, Susana Tebaldi; SILVA, Mariana Silva da. Entre a ruína e o ateliê: uma imersão poética. Revista da FUNDARTE. Montenegro, p.01-25, ano 21, no 46, setembro de 2021.

Disponível em: http://seer.fundarte.rs.gov.br/index.php/RevistadaFundarte/issue/archive $>30$ de setembro de 2021. 


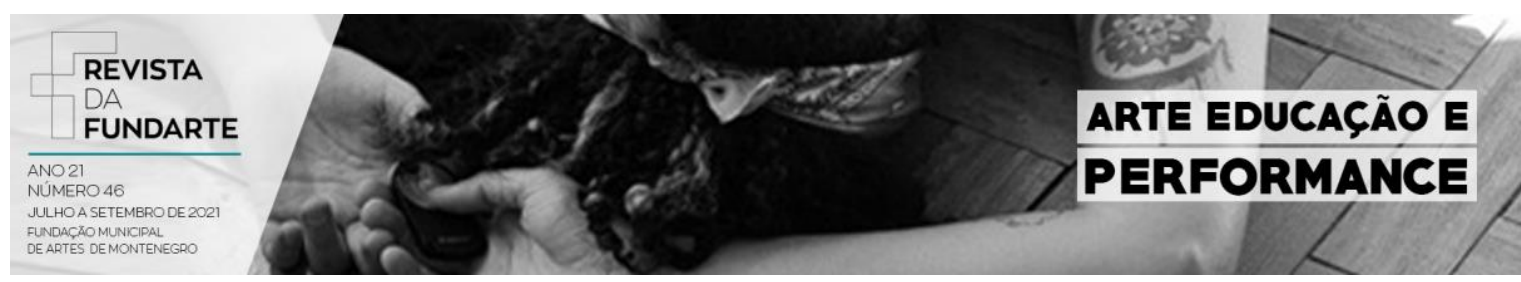

Para Augé (2003), a recordação se constrói a distância como uma proposição artística. Uma arte tão distante, contudo, que já seja digna do título de ruína, pois por mais exata que seja nos detalhes, a memória nunca constituiu a verdade de ninguém, nem de quem a desenha, pois, em última análise, essa pessoa necessita da perspectiva temporal para poder vê-la. As memórias nada mais são, assim, do que um esboço inconsciente das evoluções, uma arquitetura secreta que só pode ser descoberta à distância.

Em um primeiro momento, a ideia de compor um ateliê parecia inviável, uma vez que ainda era presente o imaginário de um espaço limpo, organizado, com diversos materiais específicos de arte, pincéis, tintas e papel, com o único intuito de produzir arte. A partir da imersão na casa e as experimentações artísticas, faz-se uso da reflexão do artista Marcelo Forte, que aponta que é possível ir "[...] percebendo que as cenas ordinárias do dia-a-dia também estão presentes e por vezes tornam turva qualquer visão romântica que se tem do ateliê." (FORTE, 2019, p. 226).

Desde essa tomada de consciência passei a ver a casa/ateliê como um campo de multiplicidades, como uma casa em devir-ateliê ou como um ateliê em devir-casa, sempre em movimentação, reterritorializando um no outro essa nova possibilidade de existência. (FORTE, 2019, p.228).

Ainda que quando Forte (2019) refere-se à casa esteja falando de sua própria moradia e não de uma casa em ruínas, é possível, também, enxergar esses movimentos e novas possibilidades no espaço escolhido para esta investigação. Entender o ateliê como um lugar de coexistências entre o que já está habitando e o vai habitar é vê-lo como:

[...] uma passagem. É, sobretudo, um entre, uma trama que articula e confunde os universos que deveria limitar: um intervalo e um trânsito entre o sagrado e profano, a arte e a vida, a arte e o mundo, o íntimo e o público, o centro e a periferia. $O$ ateliê é uma moldura habitável. (CESAR, 2002, p. 18 apud FORTE, 2019).

TOLEDO, Susana Tebaldi; SILVA, Mariana Silva da. Entre a ruína e o ateliê: uma imersão poética. Revista da FUNDARTE. Montenegro, p.01-25, ano 21, no 46, setembro de 2021.

Disponível em: http://seer.fundarte.rs.gov.br/index.php/RevistadaFundarte/issue/archive $>30$ de setembro de 2021. 


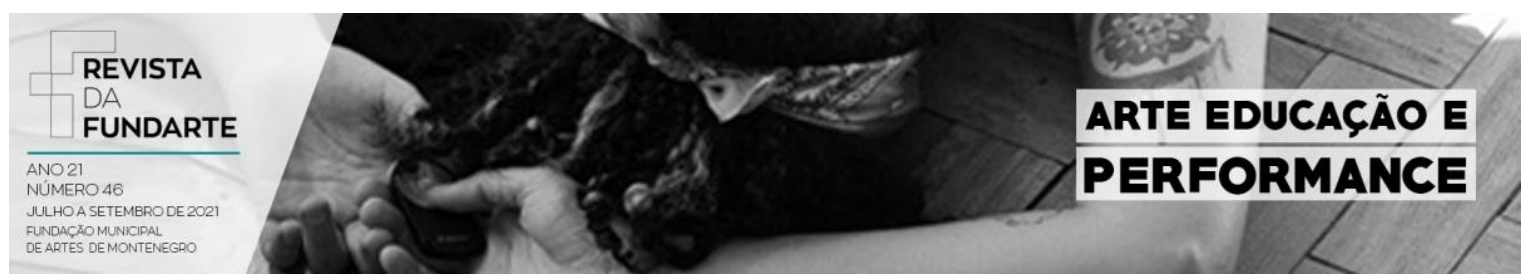

Pensamos, então, como seria possível transformar esse espaço em um ateliê artístico, em que o processo de inventar arte seja contínuo e vinculado ao tempo cotidiano. Conforme Silva, na contemporaneidade:

O ateliê se caracteriza, então, como fluxo e, para além de suas dimensões espaciais adquire, também, aspectos temporais. Muito mais do que entre, ou sem paredes, o ateliê contemporâneo se caracteriza pelo fluxo de tempo e de pessoas, trânsito e a troca com o outro. Se a contemporaneidade discute o ser exclusivo e induz a pensar um ser múltiplo e provisório, provisoriedade e processo, são instâncias a serem valorizadas, tornando-se evidentes. (SILVA, 2011, p. 72).

Historicamente, os ateliês abrigam uma variedade de artistas e já tiveram diversas configurações. Na Idade Média até o Renascimento, por exemplo, eram caracterizados como oficinas e lojas. A partir do século XVII, com a difusão de Academias de Belas Artes, passam a ser espaços de ensino formal, e no século XIX se estabelecem como estúdios de artistas com "assinatura" (GUILLOUËT; JONES; MENGER; SOFIO, 2014 apud ZORDAN, 2019, p. 2058). A partir do final do século XX, é possível pensar no ateliê como uma própria obra de arte, como coloca Paola Zordan:

[...] o ateliê surge enquanto conceito em aberto, sendo possível encontrarmos ateliês-escola, ateliês-galerias, ateliês pensados enquanto manifestações artísticas em si, tendo a Merzbau (1933), de Kurt Schwitters, como precursora de um ateliê/obra de arte. No século XXI, é possível conceber o espaço de um ateliê como meio para a arte fora dos sistemas instituídos. (ZORDAN, 2019, p. 58).

TOLEDO, Susana Tebaldi; SILVA, Mariana Silva da. Entre a ruína e o ateliê: uma imersão poética. Revista da FUNDARTE. Montenegro, p.01-25, ano 21, no 46, setembro de 2021.

Disponível em: http://seer.fundarte.rs.gov.br/index.php/RevistadaFundarte/issue/archive $>30$ de setembro de 2021. 

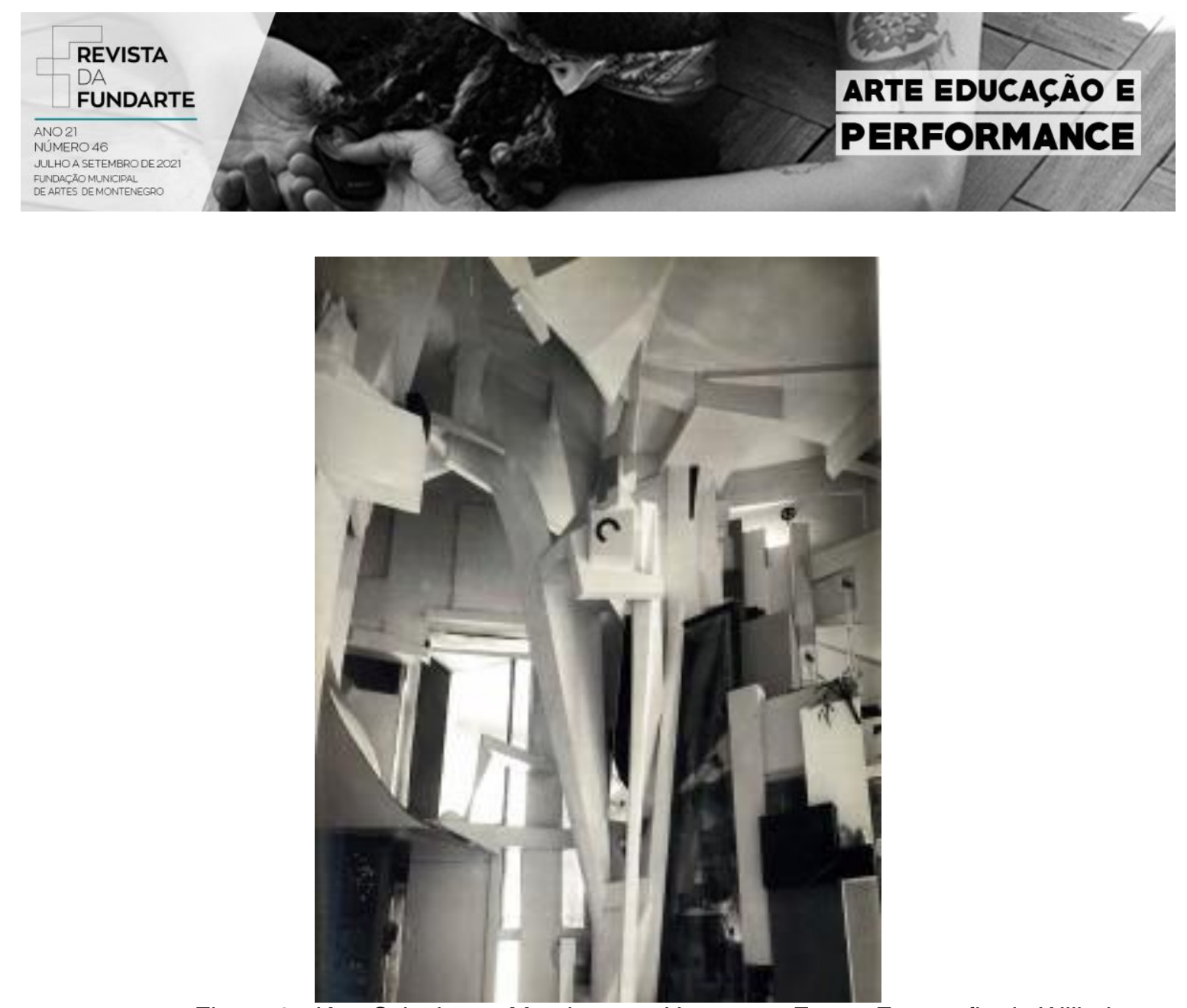

Figura 9 - Kurt Schwitters, Merzbau em Hannover. Fonte: Fotografia de Wilhelm Redemann (1933).

A Merzbau (Figura 9) foi criada na casa de Schwitters, em Hannover, na Alemanha, onde ele costumava trabalhar, ou seja, em seu ateliê, e foi consequência da mudança de relação do artista com seu trabalho, que, segundo Veronica Stigger (2008), iniciou com o abandono do uso da matéria-prima tradicional da arte e teve continuação com a troca do pincel e da tinta pela cola, pelo prego, por fragmentos de objetos encontrados. Tal fator contribui para a reformulação dos conceitos, tanto de ateliê quanto de arte em si, uma vez que a utilização de materiais não convencionais conversa com a ideia de uma arte centrada no cotidiano, fazendo um criar vinculado à vida. Para Elida Tessler, sobre Schwitters, "[...] arte é uma atividade criativa fundadora de novos movimentos nas vivências" (TESSLER, 1996, p. 63). Conforme a autora: 


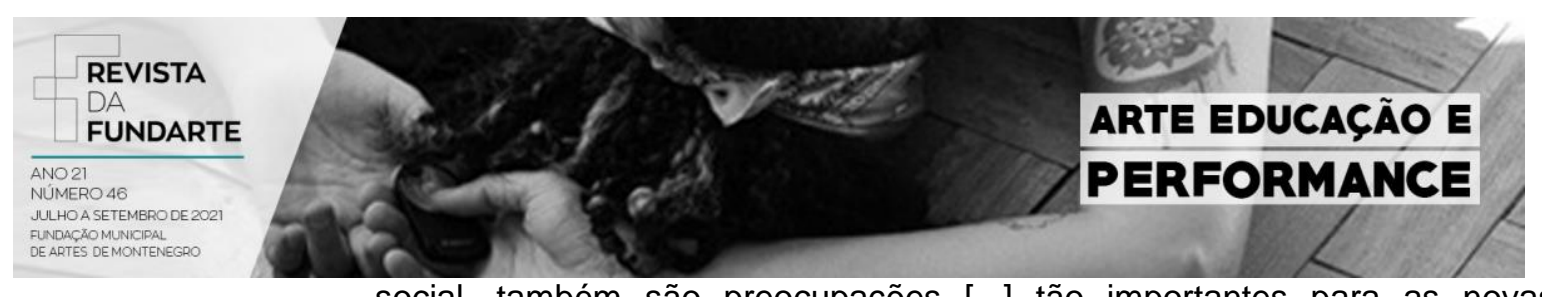

social, também são preocupações [...] tão importantes para as novas concepções da arte contemporânea em geral, que ensaiam a equação arte/vida em suas mais variadas possibilidades. (TESSLER, 1996, pp.65$66)$.

A origem da palavra ateliê vem do francês, atelier, unindo acte, traduzida para português como ato, e lier, ligar. Dando, assim, a possibilidade de pensarmos em um tecido que se borda: "bordar (escrever) sobre uma superfície (folha, corpo), delimita e demarca as bordas pelas quais se dá, ao mesmo tempo, a separação do outro (fazendo um) e a união com o outro (compondo o corpo coletivo)". (TREVISAN, 2007, p. 173-189).

O ateliê é tido, dessa forma, como instrumento de narrativização da ruína proporcionar que ela fale através da arte pode ser uma maneira de tornar suas memórias novamente habitadas. Como é o caso da proposta deste trabalho, no qual ressignifica-se o espaço casa/ruína possibilitando que a criação artística contribua para um novo habitar.

\section{(IN)CÔMODOS: Imersões cotidianas}

A vida enquanto imersão é a vida em que nossos olhos são ouvidos. Sentir é sempre tocar a um só tempo em si mesmo e no universo que nos rodeia. (COCCIA, 2018, p.37)

A partir do conceito de imersão, elaborado pelo filósofo Emanuele Coccia em seu livro $A$ vida das Plantas (2018), que apresentamos a seguir, buscou-se realizar uma imersão poética através de experimentações em arte nos cômodos da casa em ruínas.

Quando pretendemos identificar uma construção arquitetônica como casa, buscamos descrevê-la a partir das formas e funções dos espaços que ela "[...] coleta, cria e guarda: há o banheiro, a cozinha, a sala de jantar, o quarto" (COCCIA, 2020, p. 4). Para que fosse possível ressignificar esse espaço, encontrar pistas dessas formas e funções fez-se necessário para então construir novas

TOLEDO, Susana Tebaldi; SILVA, Mariana Silva da. Entre a ruína e o ateliê: uma imersão poética. Revista da FUNDARTE. Montenegro, p.01-25, ano 21, no 46, setembro de 2021.

Disponível em: http://seer.fundarte.rs.gov.br/index.php/RevistadaFundarte/issue/archive $>30$ de setembro de 2021. 


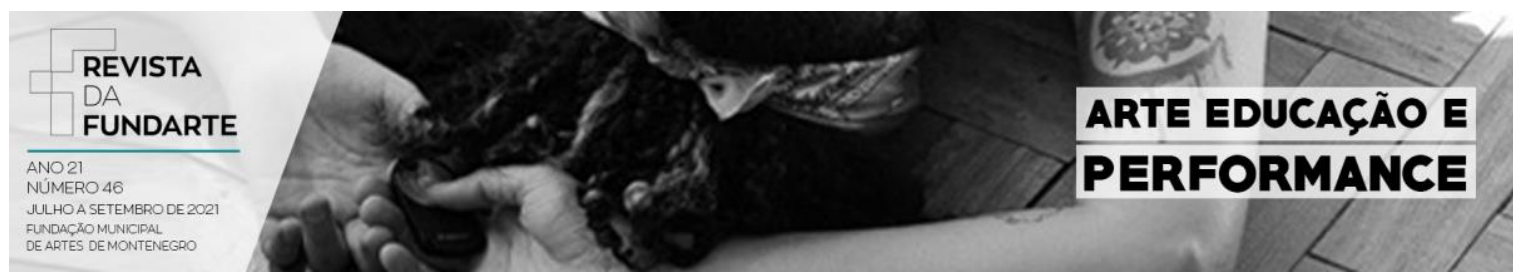

possibilidades dentro de cada cômodo. Utilizamos o termo cômodo uma vez que ele também traz consigo a acepção de conforto, agradável, fácil e satisfatório, e pretendemos, com ele, deslocar a ideia que foi construída de que a arte é somente algo belo e que agrada aos olhos.

Experimentar arte, muitas vezes, implica produzir a partir de questionamentos, incertezas e movimentos que geram reflexões. $\mathrm{O}$ incômodo que 0 passado, ou aquilo que é considerado velho e sem utilidade pode causar, impulsiona a pensar na arte como uma possibilidade de reacomodar as percepções. Para o arquiteto Juhani Pallasmaa, a arte:

[...] mais do que mediar um conhecimento conceitualmente estruturado do estado objetivo do mundo, possibilita um intenso conhecimento experimental. Sem apresentar uma proposição relativa ao mundo ou a sua condição, uma obra de arte centra nosso olhar nas superfícies que estabelecem as fronteiras entre o nosso eu e o mundo. (PALLASMAA, 2017, p. 32).

Através da criação de uma poética orientada na ideia de imergir o espaço, é possível dissolver as fronteiras que imaginamos entre nós, da espécie humana e as outras espécies da natureza, quando a imersão é entendida como:

[...] uma ação de compenetração recíproca entre sujeito e ambiente, corpo e espaço, vida e meio; uma impossibilidade de os distinguir física e espacialmente: para que haja imersão, sujeito e ambiente devem se interpenetrar ativamente; caso contrário, falaríamos simplesmente de justaposição ou de contiguidade entre dois corpos que se tocam em suas extremidades. O sujeito e o ambiente agem um sobre o outro e se definem a partir dessa ação recíproca. (COCCIA, 2018, p.41).

A tentativa de imersão foi acontecendo dia após dia, desde o trajeto na rua e a casa em ruínas, passando pelos diálogos e cafés com a proprietária da casa, pelas observações de cada detalhe, cada descascamento, cada planta, cada prego, madeira, telha até as movimentações e experimentações artísticas que vão sendo realizadas.

TOLEDO, Susana Tebaldi; SILVA, Mariana Silva da. Entre a ruína e o ateliê: uma imersão poética. Revista da FUNDARTE. Montenegro, p.01-25, ano 21, no 46, setembro de 2021.

Disponível em: http://seer.fundarte.rs.gov.br/index.php/RevistadaFundarte/issue/archive $>30$ de setembro de 2021. 


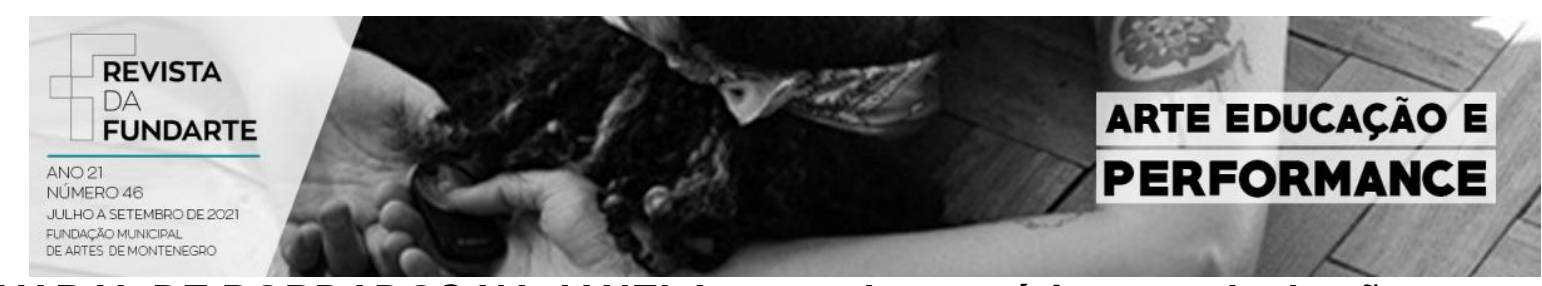

VARAL DE BORDADOS NA JANELA: tecendo memórias na sala de não estar

Ao se passar em frente a alguns tipos de ruínas, outrora casas comuns da cidade, a rapidez do olhar acaba, muitas vezes, por silenciá-las. No entanto, a casa habitada nessa pesquisa mantém sua fachada inteira, o que permite ocultar seu caráter de ruína. Os latidos de José Alfredo, Kira, Mel e Emy, cachorros e cadelas que ficam no pátio da casa, também fazem com que as pessoas que caminham pela calçada não percebam que o local não é mais uma moradia, fazendo com que a curiosidade pela vida privada seja estimulada e, conforme relatos, as pessoas espiem através dos vidros da janela.

Com o intuito de fazer um levantamento sobre olhares acerca de casas em ruínas, uma pergunta no perfil da rede social Instagram é feita: "Que palavra você associa quando vê uma casa em ruínas e/ou abandonada?"

A partir das inúmeras respostas, surge a ideia de criar um varal de bordados na janela da fachada. O varal foi construído com o intuito de substituir o papelão que é utilizado para cobrir o vidro, na possível intenção de esconder o incômodo que a ruína causa para a proprietária da casa e impedir os olhares de quem passa pela rua, pois já relatou sentir vergonha e também raiva do espaço, uma vez que existem conflitos familiares que a impedem de reformar a casa.

Por muito tempo, o fazer têxtil foi associado a questões de feminilidade, algo incômodo, pois, muitas vezes, é relacionado com enxoval, na perspectiva associada ao casamento e patriarcado. Conforme Guimarães, o bordado e os fazeres manuais contam uma história:

[...] de opressão e resistência do tecer. Violência e opressão ao ser utilizado pelos patriarcas como um instrumento de domesticação e silenciamento de mulheres. Histórias de domesticação que guardamos na memória do espaço doméstico e do labor cotidiano. Muitas das vezes o tecer é cúmplice. (GUIMARÃES, 2017, p. 2521).

Assim, o uso do bordado é uma forma de registrar a memória da casa e de sua proprietária; como uma mulher que não se rende às bordas que são, muitas

TOLEDO, Susana Tebaldi; SILVA, Mariana Silva da. Entre a ruína e o ateliê: uma imersão poética. Revista da FUNDARTE. Montenegro, p.01-25, ano 21, no 46, setembro de 2021.

Disponível em: http://seer.fundarte.rs.gov.br/index.php/RevistadaFundarte/issue/archive $>30$ de setembro de 2021. 


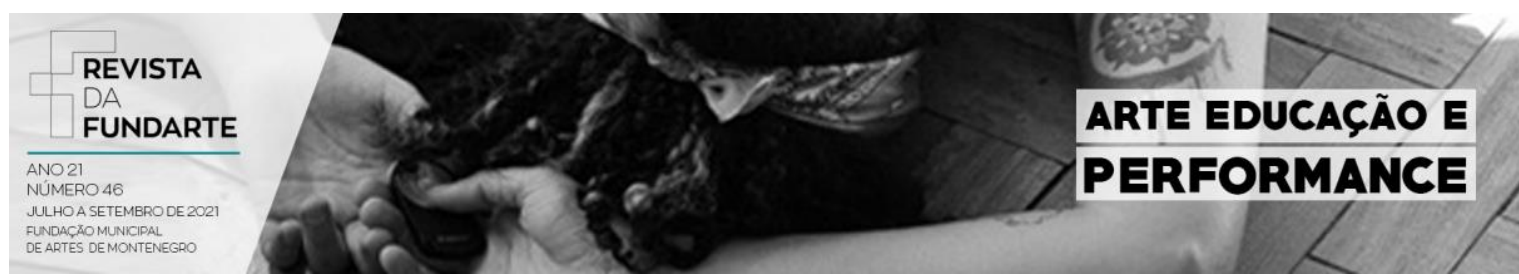

vezes, impostas às mulheres. Ela busca estar no centro de sua própria vida, tem sua autonomia através da bicicleta, deixou seus cabelos brancos surgirem, faz do cozinhar seu sustento, juntamente com sua filha, passando de geração para geração um fazer ressignificado.

Com o mesmo intuito de dar um novo significado ao ato de bordar, pensamos nele enquanto um "[...] desenhar com a linha, marcar o suporte, e desenhar não é apenas representação gráfica; é organização de pensamentos, de ideias, é origem da escrita. É repetição e ritmo, é recursividade, produz sentido. O ritmo é o que encanta e apavora" (GUIMARÃES, 2017, p. 2513).

Aos poucos, a partir de um ritmo que foge ao da produtividade em larga escala, os bordados vão surgindo em um tecido que estava guardado, que havia sido usado para um trabalho artístico e sobrou um pedaço, estava com partes mofadas. $O$ mofo também tem relação com tempo e com ruína. A escolha das cores das linhas, em um primeiro momento, se deu a partir daquelas que já tínhamos em casa, mas ao experimentar pendurar alguns bordados na janela (Figura 10), percebeu-se que algumas tinham semelhança com a paleta de cores da casa, que é ampla em função dos descascamentos (Figura 11).

Habitar uma casa, que fora moradia de uma família tradicional e que hoje encontra-se no pátio da casa de uma mulher que se descascou desses costumes tradicionais através de práticas artísticas que buscam uma quebra com os estereótipos patriarcais é construir "[...] uma rede coletiva tecida por mãos de mulheres livres, que lutam por seu projeto, que desejam lançar-se na experiência da sua própria vida" (GUIMARÃES, 2017, p. 2522).

TOLEDO, Susana Tebaldi; SILVA, Mariana Silva da. Entre a ruína e o ateliê: uma imersão poética. Revista da FUNDARTE. Montenegro, p.01-25, ano 21, no 46, setembro de 2021.

Disponível em: http://seer.fundarte.rs.gov.br/index.php/RevistadaFundarte/issue/archive $>30$ de setembro de 2021. 

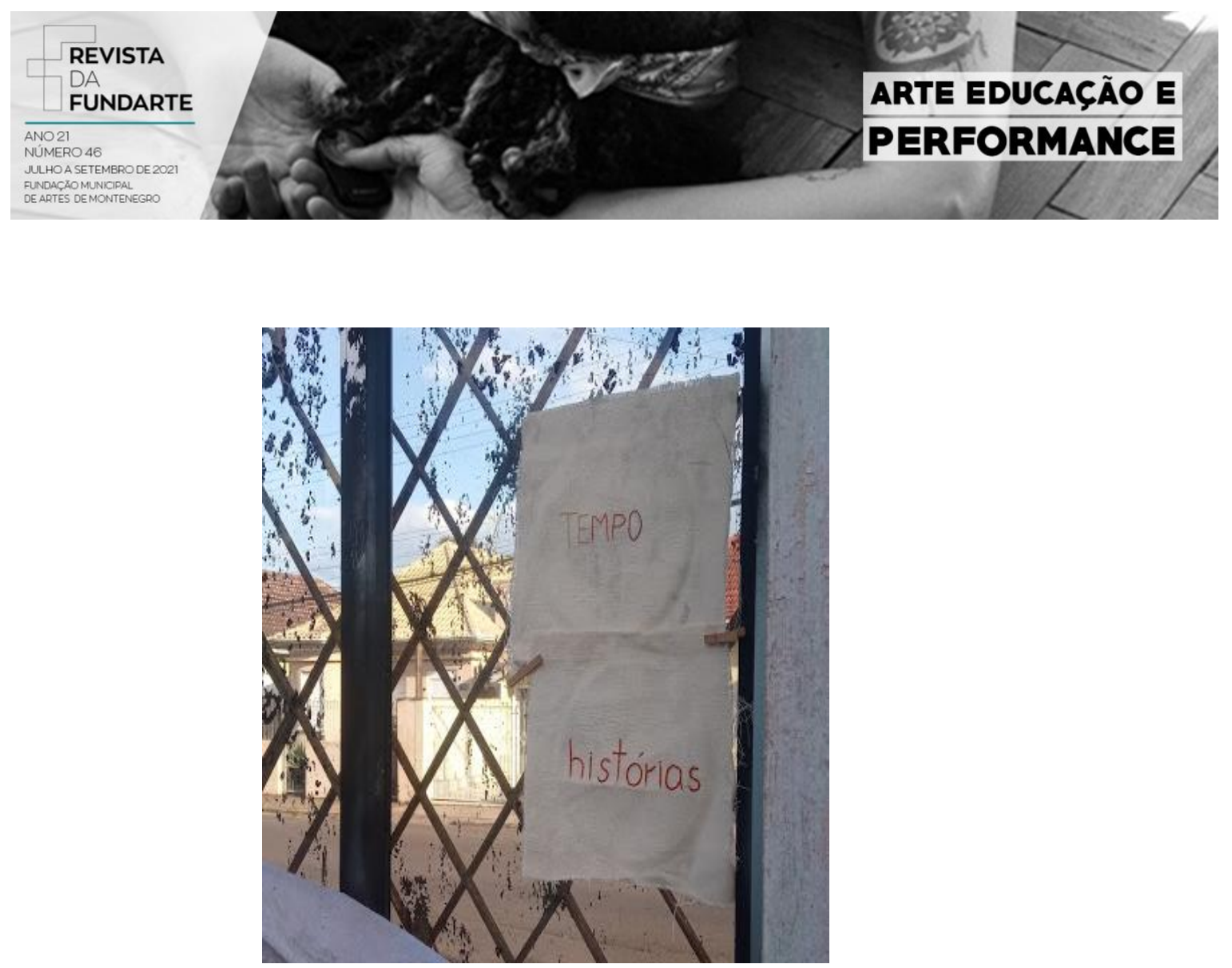

Figura 10 - Primeiros bordados colocados na janela. Fonte: Acervo pessoal (2020).

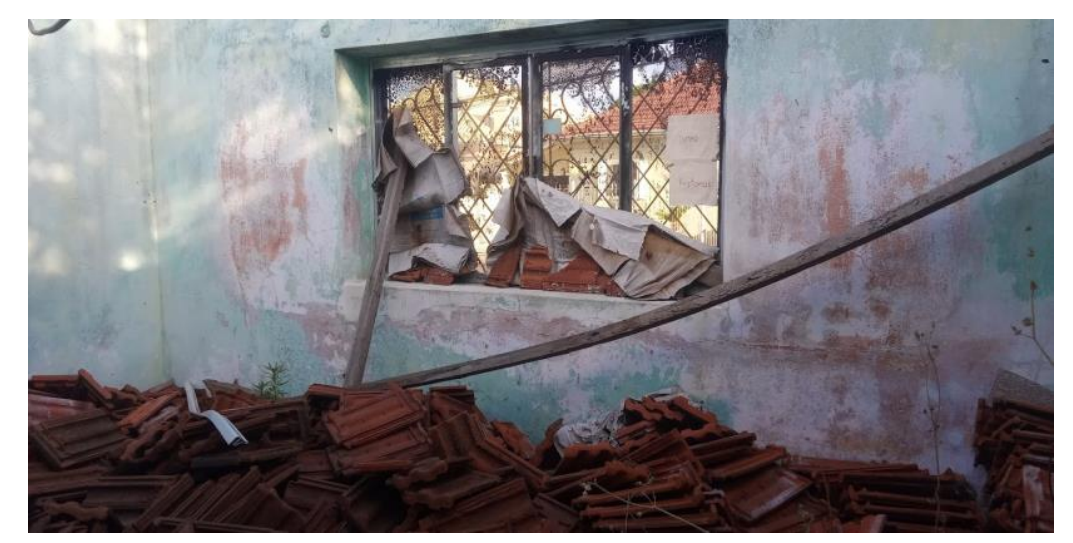

Figura 11- Parede com vários descascamentos e cores. Fonte: Acervo pessoal (2020).

A transformação desse espaço em um ateliê artístico, por e para mulheres, é também um ressignificar não só da ruína, mas também da casa enquanto espaço que deveria estar a serviço do patriarcado, conforme Guimarães (2017) questiona:

Que espaço da casa é esse que fala o século XIX e encontramos ecos, em pleno século XXI? A quem serve esse espaço opressor e silencioso que é a casa, na visão misógina e repressora de homens moralizantes e covardes,

TOLEDO, Susana Tebaldi; SILVA, Mariana Silva da. Entre a ruína e o ateliê: uma imersão poética. Revista da FUNDARTE. Montenegro, p.01-25, ano 21, № 46, setembro de 2021.

Disponível em: http://seer.fundarte.rs.gov.br/index.php/RevistadaFundarte/issue/archive $>30$ de setembro de 2021. 


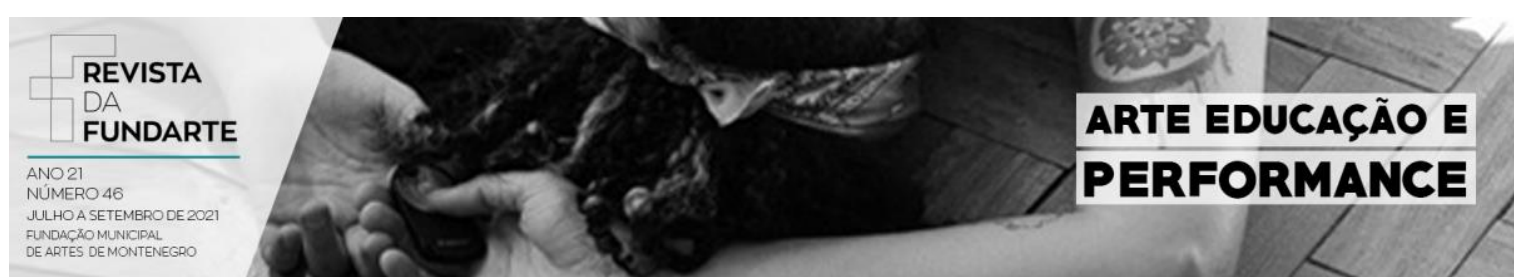

se não a manutenção de um status quo permeado por muita violência e autoridade? Consideram o espaço privado como ausente de possibilidades de leitura política, de experiência. É preciso desfazer práticas culturais naturalizadas, e desconstruir imagens estáticas dos papéis de gênero. (GUIMARÃES, 2017, p. 2522).

Coccia (2020), quando fala que uma revolução doméstica está por acontecer, nos traz que será preciso desmontar a "[...] definição patriarcal, patrimonial e arquitetônica de nossas casas e transformá-las em algo diferente" (COCCIA, 2020, p.4). Assim, quanto mais a minha imersão acontecia na casa, mais se percebia a potência poética transformadora do espaço. Cada detalhe encontrado no ambiente fazia com que imaginássemos possibilidades artísticas.

Analisamos o papelão colocado nos vidros e fizemos uso dele aplicando a prática de bordar em um processo artístico híbrido, onde cria-se e experimenta-se as linhas na superfície do papelão (Figura 12). Pois "[...] para tentar entender o mundo é preciso antes tentar compreender o espaço que habitamos, que compartilhamos com o outro. Esse espaço é construído por rotinas diárias e relações tecidas coletivamente dentro da cidade (SILVA, 2018, p.40-41).

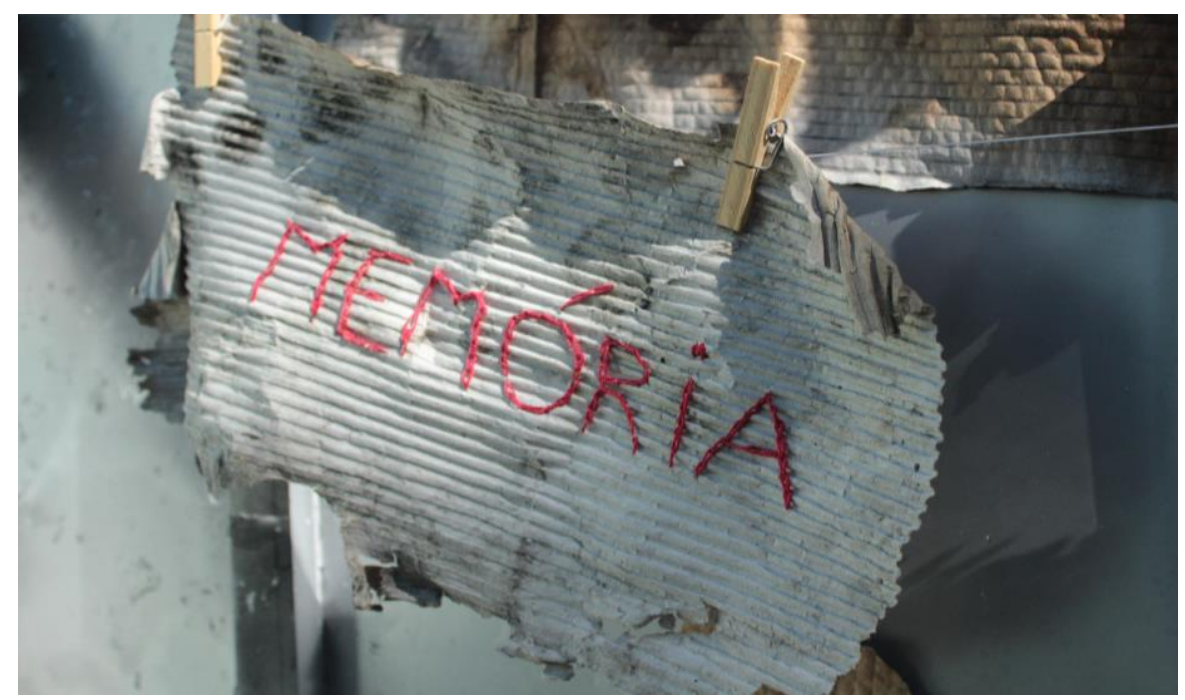

Figura 12 - Bordado no papelão. Fonte: Acervo pessoal (2020).

Esse processo artístico também se configura como híbrido, na medida em que aconteceu compartilhando o espaço com as plantas e observando seu

TOLEDO, Susana Tebaldi; SILVA, Mariana Silva da. Entre a ruína e o ateliê: uma imersão poética. Revista da FUNDARTE. Montenegro, p.01-25, ano 21, no 46, setembro de 2021.

Disponível em: http://seer.fundarte.rs.gov.br/index.php/RevistadaFundarte/issue/archive $>30$ de setembro de 2021. 


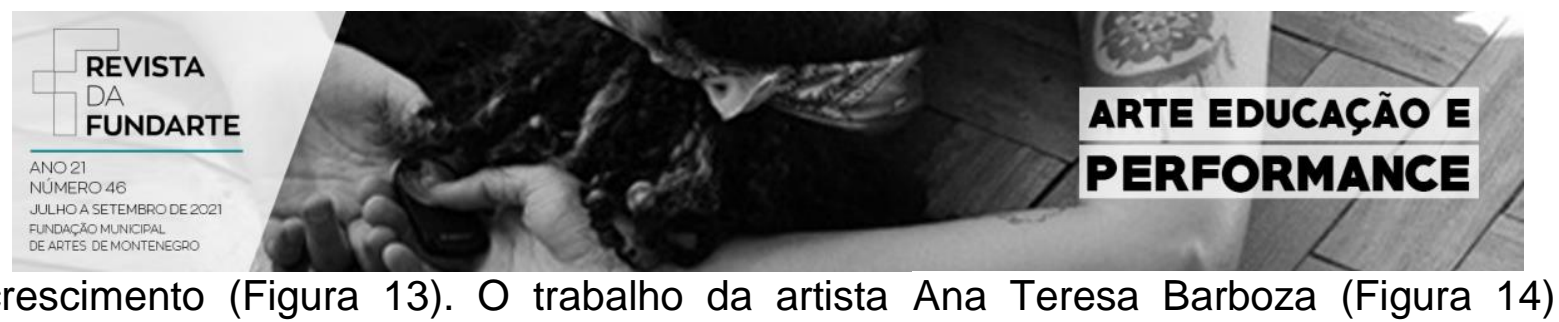

compara os processos têxteis aos "[...] ritmos de crescimento das plantas onde as técnicas de entrelaçar ou acrescentar camadas epidérmicas através do bordado, mimetizam as próprias estruturas naturais; o processo artesanal aproxima-se assim dos processos naturais." (PEREIRA, 2018).

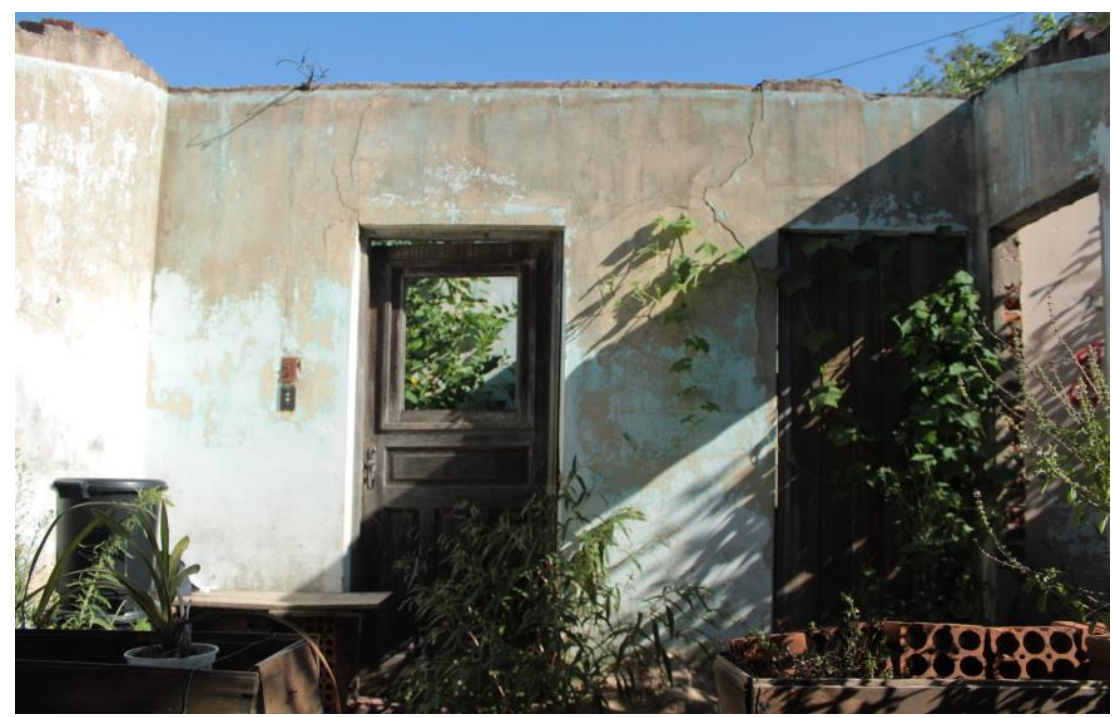

Figura 13 - Plantas que cresceram ao longo do processo. Fonte: Acervo pessoal (2021).

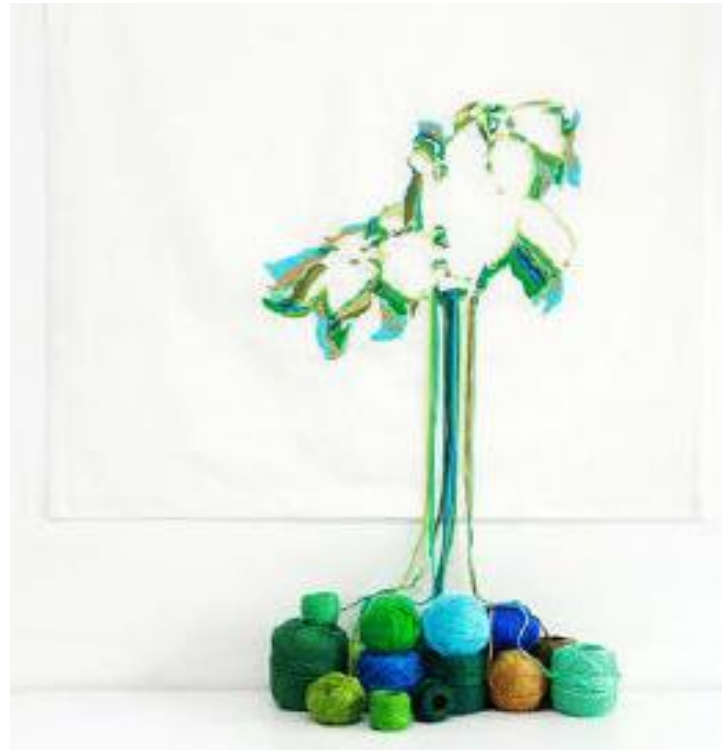

Figura 14 - Bordado sobre tecido. Fonte: Ana Teresa Barboza (2015).

TOLEDO, Susana Tebaldi; SILVA, Mariana Silva da. Entre a ruína e o ateliê: uma imersão poética. Revista da FUNDARTE. Montenegro, p.01-25, ano 21, no 46, setembro de 2021.

Disponível em: http://seer.fundarte.rs.gov.br/index.php/RevistadaFundarte/issue/archive $>30$ de setembro de 2021. 


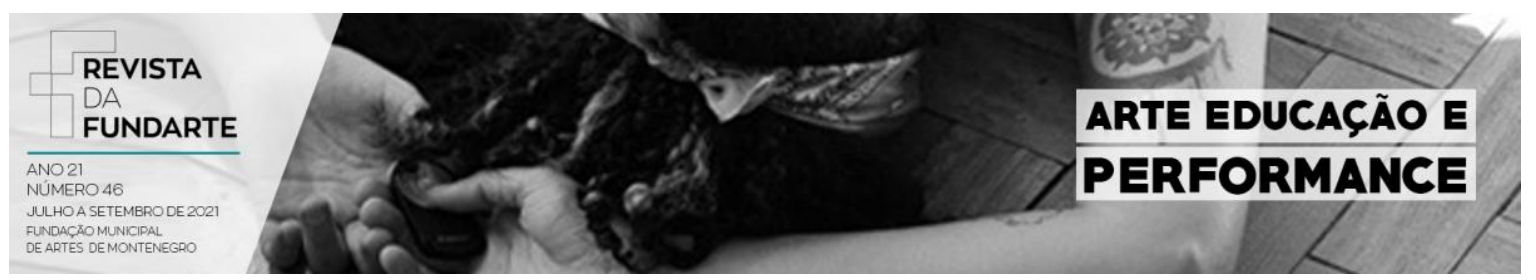

Colocar as memórias para ventilar, estendê-las no varal (Figura 15) e deixar que a potência do existir aconteça na sala onde a proprietária da casa esteve por muito tempo e agora não consegue mais estar é criar uma rede, que "[...] só existe porque existem muitos fios, feita de nós que somos nós, e daí nasce a conexão, a experiência e a palavra. A experiência precisa estar vinculada a nós mesmos, pois um fazer permite um ver" (GUIMARÃES, 2017, p. 2514).

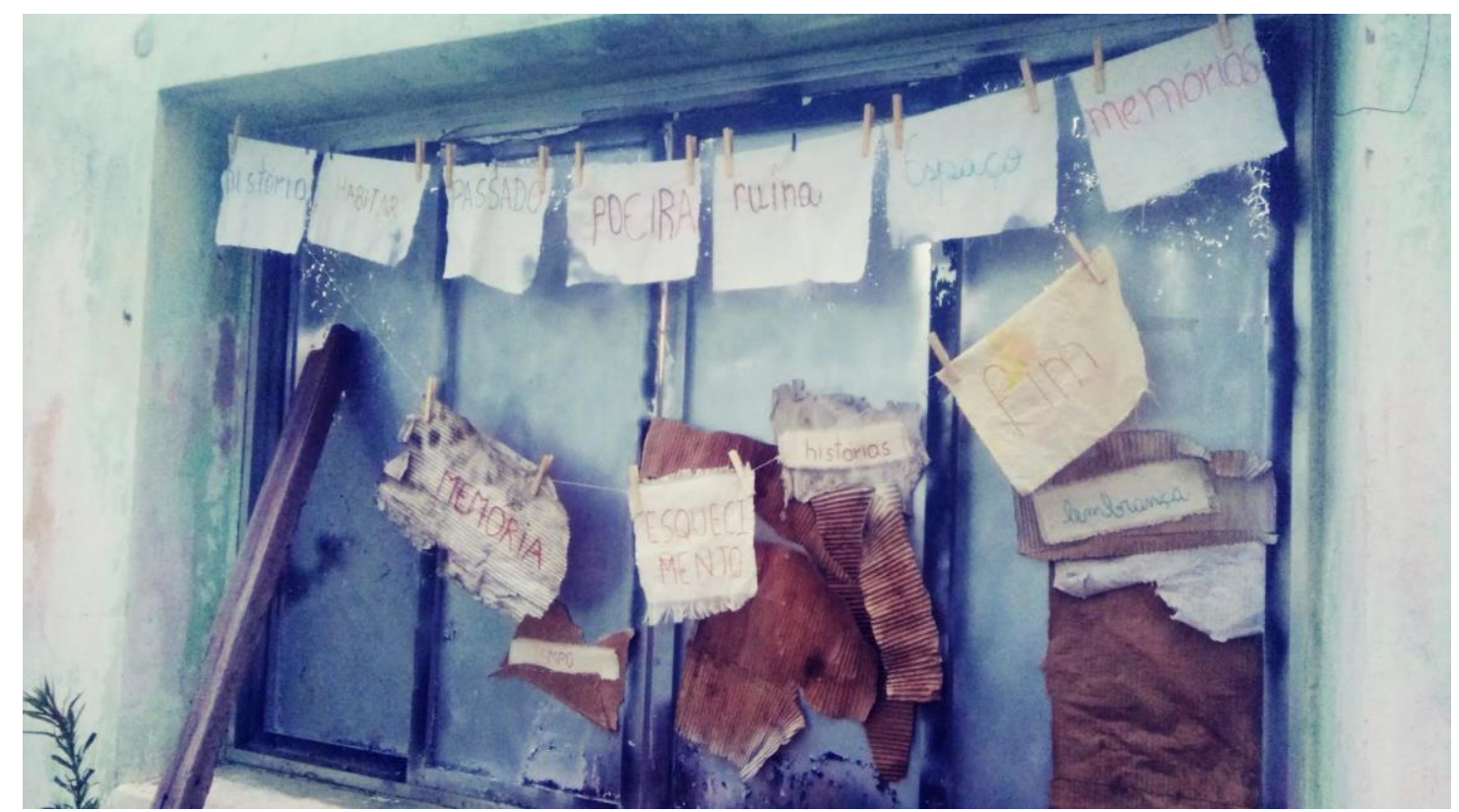

Figura 15 - Varal de memórias. Fonte: Acervo pessoal (2020).

Como a imersão poética consiste em um fazer constante e processual, outras proposições artísticas foram experimentadas no espaço da casa/ruína/ateliê, como por exemplo, um varal de cascas, um labirinto de telhas e uma banheira de aguapés que ainda estão em processo, novamente remetendo a Coccia $(2018$, p. 37), "[...] como algo que se compõe não de objetos, mas de fluxos que nos penetram e que penetramos, ondas de intensidade variável e em perpétuo movimento" e podem vir a suscitar outras ideias sobre arte e o cotidiano de habitar esse lugar, deixando sempre em aberto o desenvolvimento da imaginação e criação poética.

TOLEDO, Susana Tebaldi; SILVA, Mariana Silva da. Entre a ruína e o ateliê: uma imersão poética. Revista da FUNDARTE. Montenegro, p.01-25, ano 21, no 46, setembro de 2021.

Disponível em: http://seer.fundarte.rs.gov.br/index.php/RevistadaFundarte/issue/archive $>30$ de setembro de 2021. 


\title{
REVISTA DA \\ ANO 21
NUMMERO 46 \\ NULLHOA SETEMBRO DE 202 \\ UNDACAO MUNICIPAL

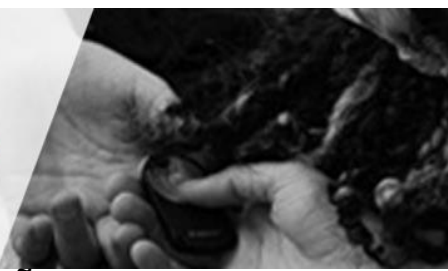 \\ क्य \\ ARTE EDUCAÇÃO E \\ PERFORMANCE \\ CONSIDERAÇÕES SOBRE HABITAR, IMERGIR E TRANSFORMAR UMA RUÍNA OU O CÉU É O LIMITE: Como a arte acontece em uma casa sem teto
}

\begin{abstract}
Como é que aposentos secretos, aposentos desaparecidos, transformam-se em moradas para um passado inolvidável? A casa nos fornecerá simultaneamente imagens dispersas e um corpo de imagens, em ambos os casos provaremos que a imaginação aumenta os valores da realidade. (BACHELARD, 2003, p. 23).
\end{abstract}

Habitar uma casa em ruínas, um espaço aparentemente abandonado, com seus cômodos ou aposentos desaparecidos, como coloca Bachelard (2003), foi uma experiência que fez refletirmos sobre nosso próprio estar no mundo. A maneira como olhamos para os lugares, as pessoas, as plantas e os animais foi se transformando juntamente com o processo de transformar o local em um ateliê.

Quando a investigação foi iniciada, utilizamos o termo abandono para nos referirmos às casas que já não eram mais uma moradia. Aos poucos, fomos percebendo que não fazia sentido, uma vez que tantas outras formas de vida estão nesses espaços. Como nos lembra Ferreira (2006, p. 4), é possível "[...] demonstrar que as ruínas, para além de serem símbolo de esquecimento, são dispositivos de afetos, capazes de potencializar a leitura de memórias".

Assim, foi com base em memórias, sejam reais ou imaginadas, que a poética desse trabalho foi sendo construída. O que foi vivenciado, recordado ou imaginado são experiências qualitativamente equivalentes, pois a comoção é possível de ser gerada a partir de algo evocado pela imaginação ou com o que realmente nos deparamos. Para Pallasmaa (2017, p. 33), "[...] a arte cria imagens e emoções que são tão reais quanto as que encontramos na vida".

A criação em arte, através de um espaço em constante transformação, ora casa, ora ruína, se deu com uma nova concepção do que vem a ser um ateliê. Como nos aponta Zordan (2019, p. 2058), "[...] um ateliê pode constituir territórios de múltiplos atravessamentos", sendo "[...] um espaço destinado à criação e ao ensino, um espaço que se configura em termos de ambiência, situação, instalação, arte in situ: um ateliê como monumento e como acontecimento" (ZORDAN, 2019, p.2060).

TOLEDO, Susana Tebaldi; SILVA, Mariana Silva da. Entre a ruína e o ateliê: uma imersão poética. Revista da FUNDARTE. Montenegro, p.01-25, ano 21, no 46, setembro de 2021.

Disponível em: http://seer.fundarte.rs.gov.br/index.php/RevistadaFundarte/issue/archive $>30$ de setembro de 2021. 


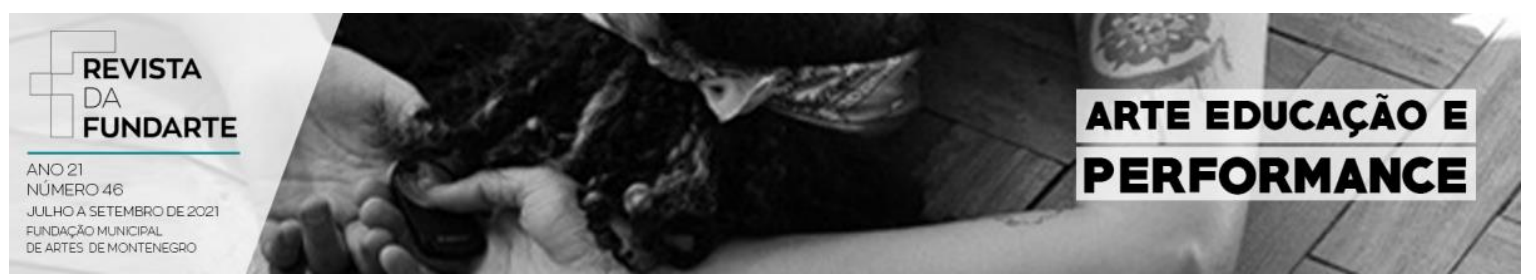

Percebe-se, assim, que tal fazer artístico foi um acontecimento, ou melhor, uma série de acontecimentos que transportam para nossas infâncias através da casa da infância de outra pessoa. Essa mescla de vivências torna-se uma constante interpenetração de seres, de formas e de presenças no mundo, ultrapassando barreiras geracionais. A partir do pensamento de Coccia (2018, p. 93-94), quando diz que: "A gente atravessa, penetra um espaço, se mistura ao mundo, mas nunca poderá se estabelecer aí. Toda habitação tende a se tornar inabitável, a ser céu e não casa". Entende-se a relação não só com a casa sem teto (Figura 27), mas com todas as casas, salas, ruas, apartamentos, praças que se habita.

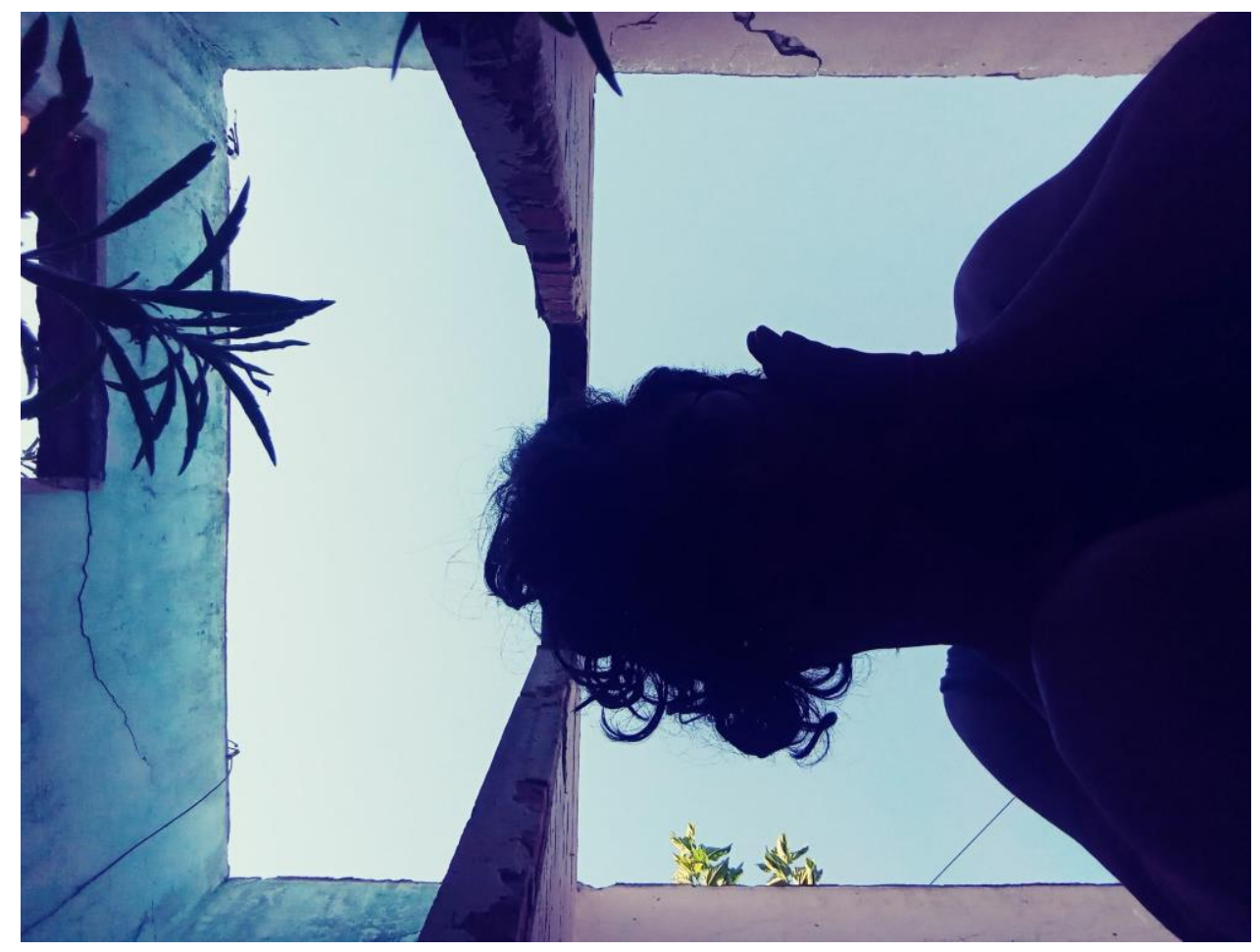

Figura 27 - O céu como telhado. Fonte: Arquivo pessoal (2020).

Entender que somos seres transitáveis, que estamos apenas de passagem nesse mundo é deslocar a visão antropocêntrica e nos colocarmos como parte da natureza, em total coabitação com todas as espécies. Ao mesmo tempo em que é interessante humanizarmos plantas, objetos, lugares, pois, como nos traz Ailton

TOLEDO, Susana Tebaldi; SILVA, Mariana Silva da. Entre a ruína e o ateliê: uma imersão poética. Revista da FUNDARTE. Montenegro, p.01-25, ano 21, no 46, setembro de 2021.

Disponível em: http://seer.fundarte.rs.gov.br/index.php/RevistadaFundarte/issue/archive $>30$ de setembro de 2021. 


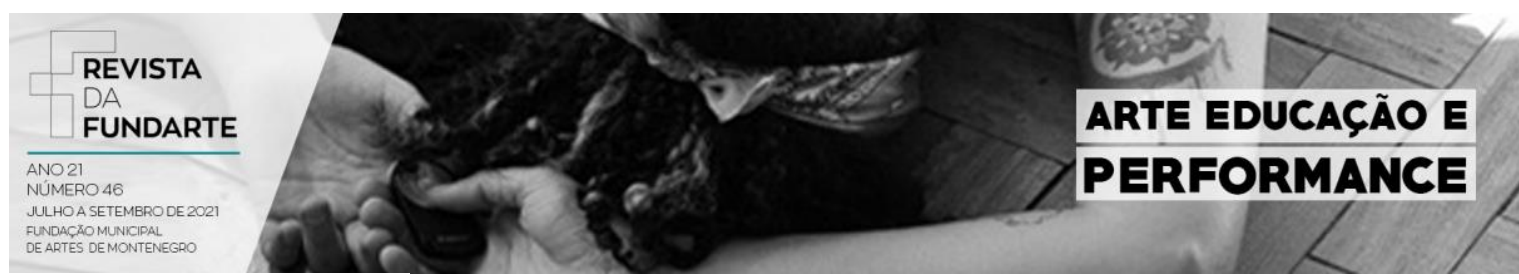

Krenak (2019, p. 24), "[...] quando despersonalizamos o rio, a montanha, quando tiramos deles os seus sentidos, considerando que isso é atributo exclusivo dos humanos, nós liberamos esses lugares para que se tornem resíduos da atividade industrial e extrativista".

Assim, as operações artísticas que habitam o espaço da casa em ruínas são as que tentam fugir das lógicas mercadológicas, que valorizam o fazer banal, que colocam o fazer da arte em um lugar de contato, de inventividade a partir do cotidiano e da vida. Para Krenak (2019, p. 33), “[...] esse contato com outra possibilidade implica escutar, sentir, cheirar, inspirar, expirar aquelas camadas do que ficou fora da gente como "natureza", mas que por alguma razão ainda se confunde com ela".

Durante esses meses de experimentação, o espaço e o ateliê foram o local de trabalho, da memória e do processo, sempre em constante fluxo e com potencial para uma continuação da pesquisa. Zordan (2019, p. 2067) salienta que "[...] criar e manter um ateliê, fora de uma instituição, é escapar da ortodoxia dos compartimentos educacionais e impedimentos políticos institucionais". Por isso, acreditamos que a arte pode estar vinculada a fazeres cotidianos e que cada canto tem potencial para ser um espaço de criação e experimentos artísticos.

\section{Referências:}

AUGÉ, Marc. El tiempo en ruina. Barcelona: Editorial Gedisa, S.A, 2003.

BACHELARD, Gaston. A poética do espaço. São Paulo: Martins Fontes, 2003.

BARBOZA, Ana Teresa. Bordado sobre tecido, 2015. Disponível em: http://www.scielo.mec.pt/scielo.php?script=sci arttext\&pid=S1647$\underline{61582018000200010}$

COCCIA, Emanuele. A Vida das Plantas: uma metafísica da mistura. Florianópolis: Cultura e Barbárie, 2018.

TOLEDO, Susana Tebaldi; SILVA, Mariana Silva da. Entre a ruína e o ateliê: uma imersão poética. Revista da FUNDARTE. Montenegro, p.01-25, ano 21, no 46, setembro de 2021.

Disponível em: http://seer.fundarte.rs.gov.br/index.php/RevistadaFundarte/issue/archive $>30$ de setembro de 2021. 


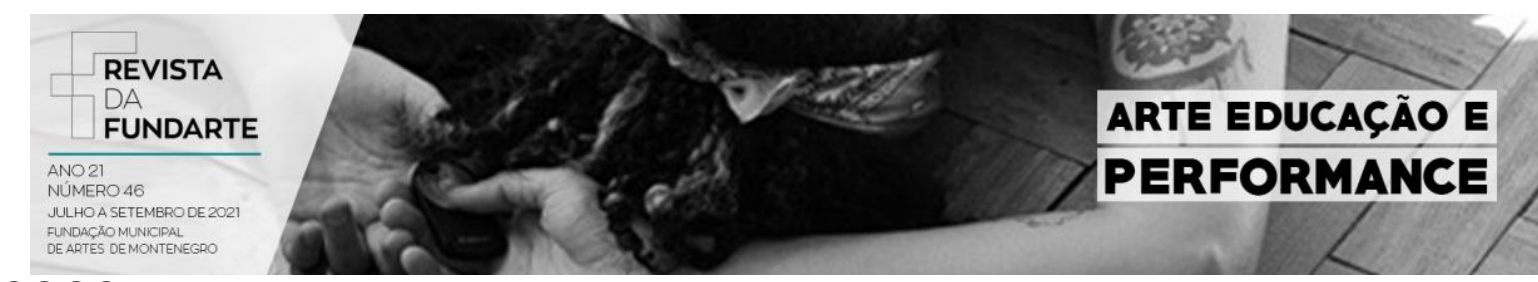

COCCIA, Emanuele. Revertendo o novo monasticismo global. Texto publicado em Fall Semester, 21 de abril de 2020. Tradução: Mariana Silva da Silva. Disponível em: $<$ http://grupoflume.com.br/wp-content/uploads/2020/04/Coccia Monastico.pdf> Acesso em: 7 out. 2020.

FERREIRA, Beatriz Rodrigues. Os silêncios da cidade: As Ruínas e suas capacidades memoriais. Anais do V encontro do Núcleo Regional Sul da Sociedade de Arqueologia Brasileira - SAB/Sul. Rio Grande, 2006. Disponível em: $<$ http://www.anchietano.unisinos.br/sabsul/V\%20-\%20SABSul/comunicacoes/37.pd> Acesso em: 3 nov. 2020.

FORTE, Marcelo. Desbravamentos de um professor-artista e os caminhos da docência-artística. 2019. 250f. Tese (Doutorado em Estudos Contemporâneos). Universidade de Coimbra, Coimbra, 2019.

GUIMARÃES, Mariana. O fio como paisagem na mediação casa, corpo e obra. In: Encontro da Associação Nacional de Pesquisadores em Artes Plásticas. 26. 2017, Campinas. Anais eletrônicos do $26^{\circ}$ Encontro da Anpap. Campinas: Pontifícia Universidade Católica de Campinas, 2017. p. 2511-2524. Disponível em <http://anpap.org.br/anais/2017/PDF/S04/26encontro GUIMAR\%C3\%83ES M ariana.pdf > Acesso em: 20 dez. 2020.

KAWAMATA, Tadashi. Destroyed Church, 1987. Disponível em: http://traac.info/blog/?p=543

KRENAK, Ailton. Ideias para adiar o fim do mundo. São Paulo: Companhia das Letras. 2019. Disponível em:

https://culturapolitica2018.files.wordpress.com/2019/09/ideias-para-adiar-o-fim-domundo.pdf Acesso em: 4 jan. 2021.

PALLASMAA, Juhani. Habitar. [Tradução e revisão técnica Alexandre Salvaterra] São Paulo: Gustavo Gili, 2017.

PEREIRA, Teresa Matos. A pele bordada, o corpo presente e o tempo tangível na obra de Ana Teresa Barboza. Estúdio, Lisboa, v. 9, n. 22, 2018 Disponível em $<$ http://www.scielo.mec.pt/scielo.php?script=sci arttext\&pid=S1647-

61582018000200010> Acesso realizado em: 8 dez. 2020.

REDEMANN, Wilhelm. Fotografia, 1933. Disponível em: https://www.moma.org/explore/inside out/2012/07/09/in-search-of-lost-art-kurtschwitterss-merzbau/

SILVA, Fernanda Pequeno da. Ateliês Contemporâneos: possibilidades e problematizações. In: Encontro da Associação Nacional de Pesquisadores em Artes

TOLEDO, Susana Tebaldi; SILVA, Mariana Silva da. Entre a ruína e o ateliê: uma imersão poética. Revista da FUNDARTE. Montenegro, p.01-25, ano 21, no 46, setembro de 2021.

Disponível em: http://seer.fundarte.rs.gov.br/index.php/RevistadaFundarte/issue/archive $>30$ de setembro de 2021. 


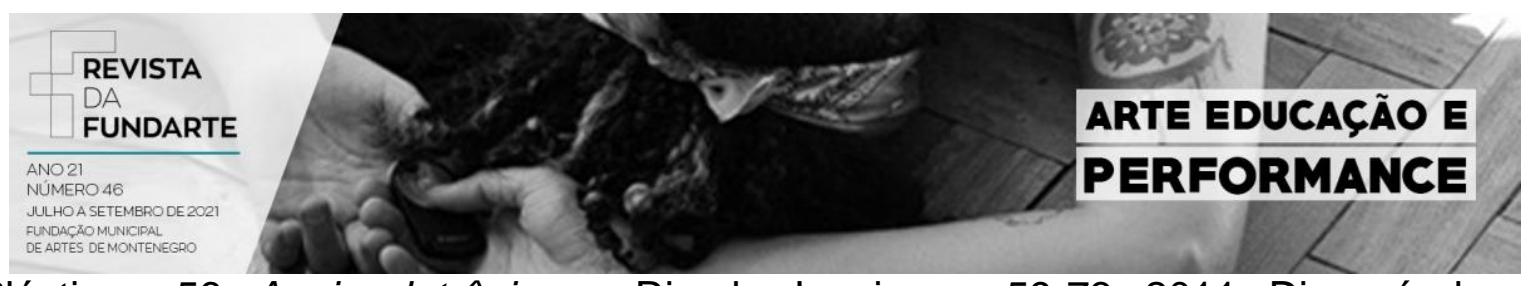

Plásticas. 56. Anais eletrônicos... Rio de Janeiro, p. 59-73. 2011. Disponível em: $<$ http://www.anpap.org.br/anais/2011/pdf/cc/fernanda pequeno da silva.pdf>

$\begin{array}{lllll}\text { Acesso } & \text { em: } & 2 & \text { dez. } & \end{array}$

SILVA, Mariana Silva da. ZONAS DE CONTATO: ressonâncias da natureza no infraordinário. 2018. 294f. Tese (Doutorado em Poéticas Visuais). UFRGS, Porto Alegre, 2018. Disponível em <https://www.lume.ufrgs.br/handle/10183/187908> Acesso em: 8 jan. 2021.

STIGGER, Veronica. A Merzbau de Kurt Schwitters e a dimensão ritual da arte moderna. Porto Arte, Porto Alegre, v. 14, n. 24, p. 95-106, 2008. Disponível em $<$ https://seer.ufrgs.br/PortoArte/article/view/27939> Acesso em: 1 jan. 2021.

TREVISAN, Ester. Atelier de escrita: a construção de um lugar de endereçamento. In: Psicose: aberturas da clínica. Porto Alegre: Libretos, 2007.

TESSLER, Elida. Formas e formulações possíveis entre a arte e a vida: Joseph Beuys e Kurt Schwitters. Porto Arte, Porto Alegre, v. 7, n. 11, p. 57-67, 1996. Disponível em: <https://seer.ufrgs.br/PortoArte/article/view/27571> Acesso em: 5 jan. 2021.

ZORDAN, Paola. Ateliê como obra de arte. In: ENCONTRO NACIONAL DA ASSOCIAÇÃO NACIONAL DE PESQUISADORES EM ARTES PLÁSTICAS, 28, Origens, 2019, Cidade de Goiás. Anais eletrônicos... Goiânia: Universidade Federal de Goiás, 2019. p. 2057-2073. Disponível em: $<$ http://anpap.org.br/anais/2019/PDF/ARTIGO/28encontro ZORDAN Paola 20 57-2073.pdf > Acesso em: 14 dez. 2020.

ZORDAN, Paola. Ateliê como prática de liberdade. Palíndromo, Florianópolis, v. 11, n. $25, \quad$ p. $\quad 50-63$, set./dez., 2019 Disponível em: $<$ https://www.lume.ufrgs.br/bitstream/handle/10183/206917/001101420.pdf?sequenc e=1\&isAllowed =y $>$ Acesso em: 15 dez. 2020.

TOLEDO, Susana Tebaldi; SILVA, Mariana Silva da. Entre a ruína e o ateliê: uma imersão poética. Revista da FUNDARTE. Montenegro, p.01-25, ano 21, no 46, setembro de 2021.

Disponível em: http://seer.fundarte.rs.gov.br/index.php/RevistadaFundarte/issue/archive $>30$ de setembro de 2021. 